\title{
Timing and mechanisms for the generation and modification of the anomalous topography of the Borborema Province, northeastern Brazil
}

\author{
J.M. Morais Neto ${ }^{\mathrm{a}, *}$, K.A. Hegarty ${ }^{\mathrm{b}, 1}$, G.D. Karner ${ }^{\mathrm{c}}$, F.F. Alkmim ${ }^{\mathrm{d}}$ \\ ${ }^{a}$ PETROBRAS, EEP-EXP, Equatorial Margin Exploration Team, Rio de Janeiro, Brazil \\ b 572 Balcombe Road, Black Rock, Victoria 3193, Australia \\ ${ }^{\mathrm{c}}$ ExxonMobil Upstream Research Company, Houston, TX 77252-2189, USA \\ d Universidade Federal de Ouro Preto, Escola de Minas/DEGEO, Ouro Preto, MG, Brazil
}

\section{A R T I C L E I N F O}

\section{Article history:}

Received 1 March 2008

Accepted 2 July 2008

Available online 11 July 2008

\section{Keywords:}

Apatite fission-track analysis

Post-rift uplift

Landscape evolution

Denudation

Borborema Province

Northeastern Brazil

Brazilian Equatorial Margin

\begin{abstract}
A B S T R A C T
The results of apatite fission-track analysis in 14 granitic-gneissic samples from two regional transects across the Borborema Plateau, northeastern Brazil, show evidence for two dominant paleothermal events: a Late Cretaceous cooling event beginning sometime between 100 and $90 \mathrm{Ma}$, and a second cooling event in the Neogene. The distribution of the fission-track results suggests that the cooling events have a broad regional expression and are consistent with the geologic record in the Araripe Basin, western Borborema Province, which attests to a post-Albian uplift of the whole region. We hypothesize that the first event is due to the uplift and denudation of regional, permanent topography generated after the breakup of Brazil and Africa. Such topography is predicted by models of continental margin extension in which continental lithosphere thinning is followed by thickening of the adjacent hinterland lithosphere and crust (Kusznir, N.J., Karner, G.D., 2007. Continental lithospheric thinning and breakup in response to upwelling divergent mantle flow: application to the Woodlark, Newfoundland and Iberia margins. In: Karner, G.D., Manatschal, G., Pinheiro, L. (Eds), Imaging, mapping and modeling continental lithosphere extension and breakup. Special Publication 282, Geological Society, London, pp. 389-419.). In northeastern Brazil, this extension-engendered topography may have been amplified by magmatic underplating related to the Saint Helena and Ascension plumes. The Miocene cooling event (20-0 Ma) occurred at a time characterized by the transition from carbonate ramp to progradational clastic systems on the Pernambuco-Paraíba margin and the offshore Potiguar Basin. This same stratigraphic response characterizes the Neogene stratigraphy of many passive margins and attests to a global increase in the delivery of clastics to margins, the simplest explanation of which is a climate change that accentuated erosion of pre-existing topography. Thus, the present rugged landscape of northeastern Brazil is interpreted to be a product of this younger denudation event. A corollary of this study is that the history, distribution and delivery of clastics to the northern and northeastern margins of Brazil are a function of the regional development of the continental landscape during the Late Cenozoic.
\end{abstract}

(c) 2008 Elsevier Ltd. All rights reserved.

\section{Introduction}

The Borborema Province, a large cratonic shield area in northeastern Brazil (Fig. 1), underwent significant uplift during and after Cretaceous times, as indicated by many lines of evidence, most notably the shallow-water Albian limestones in the Araripe Basin (western Borborema Province) at present elevations of 700-800 m above sea level.

\footnotetext{
* Corresponding author. Present address: The University of Queensland, Earth Sciences, Steele Building, St. Lucia Campus, 4072 QLD, Australia. Tel.: +617 3365 2176; fax: +61 733651277.

E-mail address: jmarinho@petrobras.com.br (J.M. Morais Neto).

1 Formerly at GEOTRACK International Pty. Ltd., Brunswick West, Victoria, Australia.
}

The main topographic expression of this uplift is the Borborema Plateau, which shows maximum elevations on the order of $1200 \mathrm{~m}$ above sea level and encompasses almost the whole northeastern shield of Brazil. The Borborema Plateau shows a regional axis oriented in the NE-SW direction. It is surrounded by marginal lowlands (the "Sertaneja Depression" and the coastal cuestas) (Fig. 2). Within the Borborema Plateau area, there are several mesas partially covered by the sediments of the Serra do Martins Formation, a sequence of continental sandstones and conglomerates of presumed Paleogene age. The occurrence of these sediments at high elevations also has been viewed as evidence for Cenozoic uplift affecting at least the eastern Borborema Province and possibly beyond. However, the sediments of the Serra dos Martins Formation are non-fossiliferous and the stratigraphic age has been inferred from fission-track analysis (Morais Neto et al., in press) and 


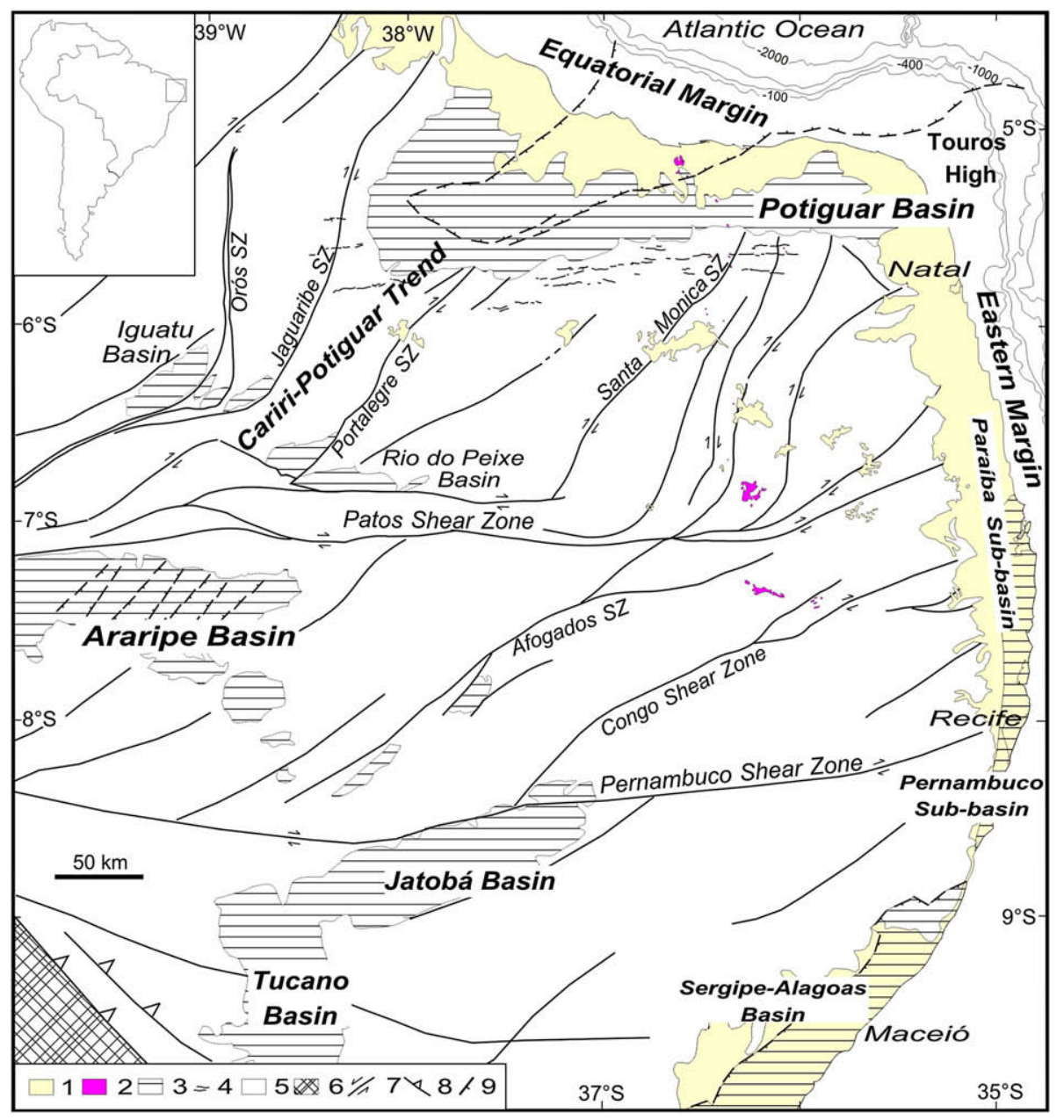

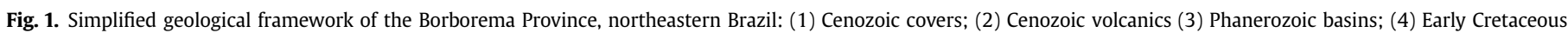
Tholeiitic Dike Swarm (5) Precambrian crystalline rocks; (6) São Francisco craton; (7) Precambrian shear zones; (8); Thrusts; (9) Early Cretaceous rifts.

indirect relationships with Cenozoic volcanics (Menezes et al. 2003; Jardim de Sá et al., 2005).

During the last three decades, many hypotheses have been formulated to explain the morphological evolution of the Borborema Province, in particular, and the timing and causative mechanisms for the regional topography of northeastern Brazil, in general. These studies, mostly based on morphoclimatic arguments, interpreted the development of the Borborema Province using regional correlations of distinct (and undated) peneplained surfaces. Using these correlations, many authors assigned a range of ages for the planation surfaces and their "correlative" sediments, leading to many redundant, controversial, and sometimes inconclusive correlations. Rather than to rely on non-fossiliferous, continental deposits to constrain the timing of uplift, we used apatite fissiontrack analysis (AFTA) on samples from the Borborema Plateau region and surrounding areas to provide a quantitative constraint on the timing of various cooling (or paleothermal) events and thus insights into the timing of formation and denudation of the topography of northeastern Brazil.

In regions such as the Borborema Plateau, where large periods of geological time are not represented in the geological record, thermal history tools are unusually powerful in studying the nature of events during time intervals unrepresented in the preserved rock record. Constraints from thermal histories provide a unique opportunity to better understand important aspects of the Phanerozoic tectonic evolution of a region that is presently dominated by only Precambrian terrain. In this paper, we present the results from 14 apatite fission-track analysis, which provide new quantitative constraints on the thermal history of this region by constraining the timing of cooling, such as caused by uplift and/or topographic denudation, from the thermal history of individual samples. In addition, we evaluate models for the generation of regional, permanent continental topography, and discuss possible mechanisms responsible for the development of the present-day topography of the Borborema Province in terms of post-rift thermal events related to the breakup of Gondwana, tectonics and climate changes.

The origin of the positive long wavelength topography of northeastern Brazil remains enigmatic, both in terms of its timing and causative mechanism (Hegarty et al., 2004). Topographic relief distributed over many 100 s of kilometers can be generated via a number of first-order processes, such as thin- and thick-skinned folding and thrusting of the crust, mantle plume activity, lithosphere delamination, and magmatic underplating of the crust. While extension can generate flanking flexural topography, the distribution tends to be spatially limited, with asymmetric flank width generally being between 100 and $200 \mathrm{~km}$. These mechanisms generate permanent topography, which is in contrast to the transient topography engendered by solely thermal processes. Magmatic underplating, by effectively thickening the crust, leads to permanent topography coeval with the underplating (Brodie and White, 1995). 


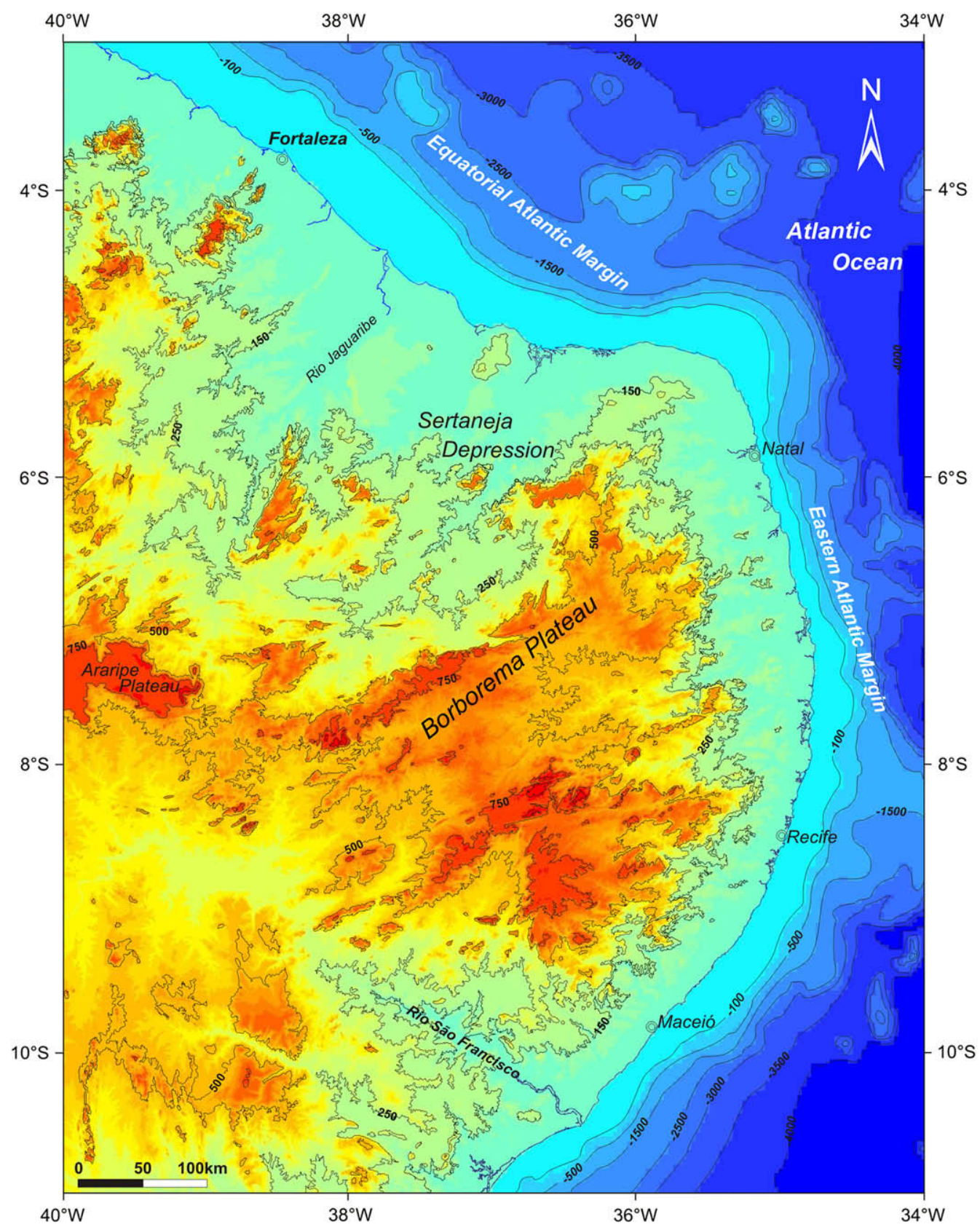

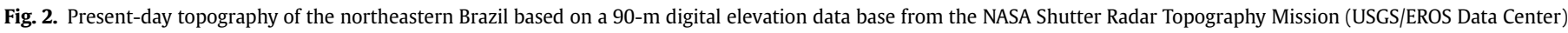
Bathymetry of the Atlantic sea-bottom simplified from Cherkis et al., 1989.

Recent studies by Davis and Kusznir (2004) and Kusznir and Karner (2007) have shown that depth-dependent lithospheric thinning, in which stretching of the lower crust and lithosphere mantle greatly exceeds that of the upper crust, a characteristic of many non-volcanic and volcanic rifted continental margins, can be modeled by an upwelling divergent flow model of continental extension. Such a model successfully predicts both observed depth-dependent lithosphere stretching and mantle exhumation at rifted continental margins. In this model, extension produces an outward flow of asthenosphere material towards the hinterland, thickening the adjacent continental lithosphere at distances beyond the region of localized rifting and lithospheric thinning; the immediate response to lithosphere thickening in the hinterland is to decrease the lithosphere geothermal gradient. Modeling shows that the subsequent re-equilibration of the continental hinterland lithosphere geotherm generates uplift of 400-600 m over a timescale controlled by the lithosphere thermal reequilibration time-constant of 60-100 m.y. Interfluve topography would be further amplified by isostatic rebound in response to topographic erosion. The lateral wavelength of uplift is of the order of 400-600 km wavelength. This upwelling divergent flow model of continental extension, possibly amplified by magmatic underplating when mantle plumes exist in the region (e.g., active rifting and volcanic margins), presents a promising mechanism to help explain regional post-breakup uplift over timescales of 50100 m.y. in the Brazilian hinterland, in particular, and adjacent to passive continental margins, in general.

Knowledge of when and where clastics are delivered to an evolving continental margin is essential for hydrocarbon exploration in terms of predicting the general location, timing, and the 
sand content and maturity of turbidite deposits. Such predictions require information about the history of topography generation, modification, and denudation. Continental landscapes are constantly in a state of flux as drainage systems evolve and interact via the process of river capture during the denudation of topography. In turn, any post-rift tectonics that modifies or generates topography will play a major role in this landscape evolution process, controlling the transport and delivery of clastics by fluvial systems to the margins. Rivers represent point sources of clastics along margins, however, their distribution, energy, and sediment content are prime functions of topography generation and distribution. Once deposition takes place, marine processes such as alongshore drift rework and redistribute the sediments along the margin. During eustatic falls, margins associated with relatively large fluvial systems will tend to be associated with significant drainage rejuvenation, river incision of the exposed shelf, canyon development, and given suitable conditions, the deposition of turbidities. A corollary of this study is to provide suggestions about when clastics from the eroding Borborema topography, as modified by the development and interaction of intracontinental drainage systems, should be delivered to the northern and northeastern Brazilian basins. While this is a local study of the Borborema Province of northeastern Brazil, the implications of this work have far reaching consequences for the stratigraphy of rifted continental margins through the development of hinterland topography.

\section{Geological setting}

The Precambrian Borborema Province in northeastern Brazil (Fig. 1) consists of a gigantic fan-like system of right-lateral strikeslip shear zones, juxtaposing Archean to Mesoproterozoic crystalline massifs against belts of Neoproterozoic metasediments (Van Schmus et al., 1998; Dantas et al., 1998). The Borborema strike-slip system corresponds to the west-central portion of the Pan-African/ Brasiliano orogenic collage formed during the Neoproterozoic assembly of West Gondwana (600-580 Ma). The main shear zones of the system, namely the Pernambuco, Patos, Portalegre, PicuíJoão Câmara, Santa Mônica, Remígio-Pocinhos and Senador Pompeu shear systems, show orientations varying between E-W and NE-SW (Fig. 1). These structures seem to accommodate large strains in a context of continental collisions involving lithospheric segments of distinct rheological properties; in such continental collisions, rheological competent blocks act as indentors that generate strong shear zone systems as the rheological weaker blocks are squeezed out or "escape" laterally (Jardim de Sá, 1994; Vauchez et al., 1995; Brito Neves et al., 2000).

The fragmentation of Gondwana in the Mesozoic is recorded in northeastern Brazil by a series of tectonic and magmatic events, including the development of basins in the continent interior and the Atlantic passive margin. The WNW-ESE and N-S trending segments of the Brazilian continental margin are commonly referred to as Equatorial and Eastern margins, respectively (Fig. 1). These segments, which meet in the region northeast of the Borborema Province, experienced distinct tectonic histories, reflecting two distinct tectonic regimes. The Equatorial segment corresponds to a transform margin, whereas the Eastern segment evolved as a classical divergent, "passive" margin (Matos, 1999).

The structuring of the Eastern and Equatorial Margins started with intense crustal stretching during the Mesozoic, which led to the formation of three main Neocomian rift systems in northeastern Brazil: Recôncavo-Tucano-Jatobá and Sergipe-Alagoas, as well as the basins along the Cariri-Potiguar Trend (Figs. 1 and 3). The geometry of these basins was controlled and compartmentalized by the complex network of Proterozoic shear zones.

The Cariri-Potiguar Trend (Matos, 1992) is formed by several intracontinental rift basins along a NE-SW axis in the northwestern vicinity of the Borborema Plateau. This trend encompasses small Neocomian (140-118 Ma) basins such as the Rio do Peixe, Iguatu and Icó, and the sub-surface rift sections of the Araripe and Potiguar Basins (Fig. 1), which were aborted during the Barremian in favor of eventual crustal breaching and ocean crust generation to the north and east. The Sergipe-Alagoas Basin on the Eastern continental margin (Fig. 1) is composed of a series of half-graben bounded by N-S, NW- and NE-trending faults (Lana, 1990), also formed during the Neocomian and contains a complete record of both syn-rift and post-rift sediments. Pre-rift sediments include Paleozoic and Jurassic intracratonic sediments. The Recôncavo-Tucano-Jatobá rift system (Fig. 1), also formed during the Neocomian, extends to $400 \mathrm{~km}$ in $\mathrm{N}-\mathrm{S}$ direction in the region south of the Borborema Province (Fig. 1). This system consists of asymmetric grabens separated by basement highs and accommodation zones (Magnavita et al., 1994).

\section{Continental rifting and breakup}

In the northeastern portion of the Borborema Province, the breakup of Western Gondwana was preceded by the outpouring of the Rio Ceará-Mirim tholeiites from the late Jurassic to Barremian (145-125 Ma; Fig. 1). South of the Potiguar Basin, this magmatism is represented by an extensive $\mathrm{E}-\mathrm{W}$-trending dike swarm (Figs. 1 and 4). O'Connor and Duncan (1990), Wilson (1992), Lima Neto (1998b) and Oliveira (1998), for instance, argued that this igneous activity was mantle plume induced. It was further suggested that these plumes (possibly the Saint Helena and Ascension plumes) might have played an important role in the weakening of the lithosphere and in the extension and breakup of the South American and African plates. As such, the Eastern Brazilian margin represents a volcanic rifted margin, a classification supported by the existence of seaward dipping reflectors within the SergipeAlagoas Basin (Mohriak et al., 1998, 2002), and by syn-rift volcanic activity within the Pernambuco-Paraíba Basin (Jardim de Sá et al., 2004; Almeida et al., 2005).

North of the Potiguar Basin (Fig. 1), continental breakup and seafloor spreading is interpreted to have commenced in the Late Aptian/Early Albian. In the Pernambuco sub-basin (the southernmost portion of the Pernambuco-Paraíba Basin; Fig. 1), a late synrift magmatic event generated granites and alkali volcanics dated between 105 and $97 \mathrm{Ma}$ (Long et al., 1986; Jardim de Sá et al., 2004). The establishment of open marine conditions between eastern South America and Africa is considered to be of Late Albian age (Koutsoukos, 1992).

After continental breakup, the margin underwent lithospheric cooling and subsidence, as recorded in the Potiguar Basin (Fig. 3) by a lower Albian-Campanian transgressive sequence and by an upper Campanian to Recent regressive megasequence (Araripe and Feijó, 1994; Cremonini et al., 1998; Soares et al., 2003). Major hiatuses exist within the transgressive megasequence in the Potiguar Basin (Pereira, 1994; Gil, 1996); these authors have interpreted a Late Turonian (ca. $89 \mathrm{Ma}$ ) subaerial unconformity developed across the Jandaíra Formation carbonate platform to be the result of tectonically-induced uplift and erosion across the margin. A short magmatic event (the "Cuó Volcanism") in the onshore Potiguar Basin around 93 Ma (Oliveira, 1998; Souza et al., 2004) has been interpreted to be the consequence of this tectonic event.

Further, the formation of a widespread erosive unconformity at about $78 \mathrm{Ma}$ across both the onshore and offshore Potiguar Basin has been attributed to plate tectonic reorganization of the central Atlantic (Gil, 1996). Cremonini and Karner (1995) and Cremonini (1996) pointed out that during the mid Campanian, the passage of an oceanic spreading center along the Equatorial Margin might have caused regional heating, uplift and erosion, as well as tectonic reactivation. The main expression of this event would be the raising 


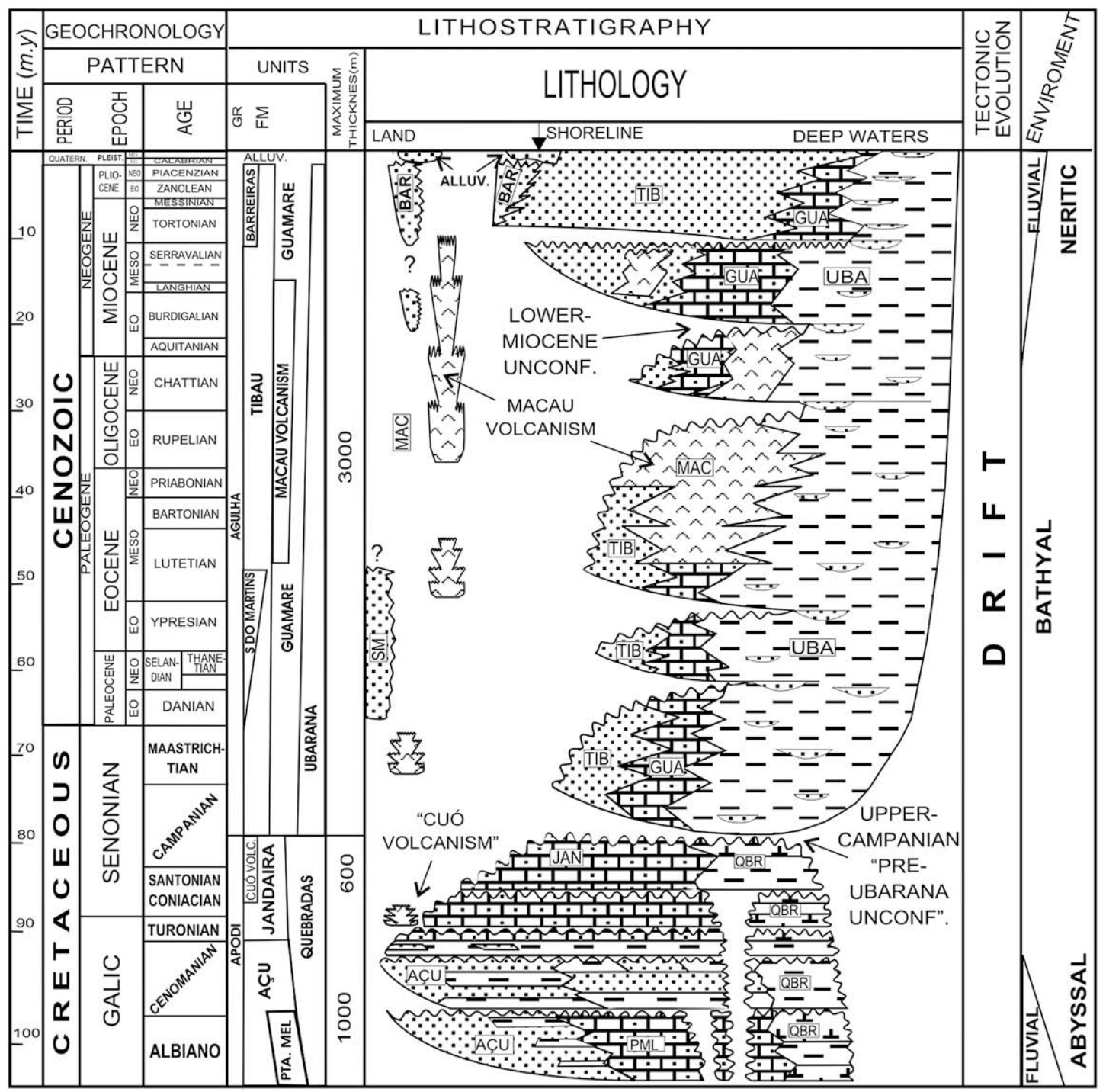

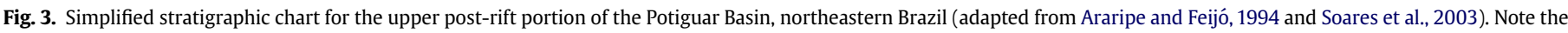

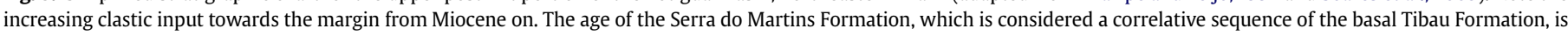
estimated by fission-track data (Morais Neto et al., in press) and indirect relationships with upper Oligocene volcanics (Menezes et al., 2003; Jardim de Sá et al., 2005).

of the carbonate platform of the Jandaíra Formation and the consequent generation of a regional unconformity, the "preUbarana unconformity" of the Potiguar Basin. It is speculated that the entire region affected by the thermally-induced uplift subsided once the spreading center had passed.

Two non-fossiliferous sedimentary units of Cenozoic age cover Precambrian crystalline rocks and Cretaceous sediments in isolated portions of the Borborema Province: the Serra do Martins and the Barreiras formations. The Serra do Martins Formation is a sequence of immature and coarse-grained continental sandstones and conglomerates that constitute the remnant cover of several mesas in the Borborema Plateau area at altitudes from 500 to $760 \mathrm{~m}$. Apatite and zircon fission-track analysis on those sediments suggests that the Serra do Martins Formation cannot be older than Paleogene (Morais Neto et al., in press), and indirect relationships with Oligocene volcanics suggest that the Serra do Martins Formation is older than $\sim 25$ Ma (Menezes et al., 2003; Jardim de Sá et al., 2005). The Barreiras Formation is a sequence of siliciclastic sediments that form cuestas along the coast; the age of their deposition has been estimated as Miocene
(Arai et al., 1988; Shimabukuro and Arai, 1999) or PliocenePleistocene (Mabesoone et al., 1972; Bigarella, 1975), but recently Lima et al. (2007) constrained the depositional age of the Barreiras Formation to be $22-17 \mathrm{Ma}$, based on ${ }^{40} \mathrm{Ar} /{ }^{39} \mathrm{Ar}$ and (U-Th)/ He geochronology of weathering profiles in the Potiguar Basin area.

From Maastrichtian to Miocene, at least five important magmatic pulses, represented by volcanic necks, plugs, and basaltic lava flows of the so called "Macau Formation" (Figs. 3 and 4), affected the northern Borborema Province. These alkaline volcanics range in age from 72 to $7 \mathrm{Ma}$ (Souza et al., 2004). In the offshore Potiguar Basin, successive lava flows form a relative thick package of Eocene-Oligocene basalts, which have been related to the interaction of the Equatorial Margin with the Fernando de Noronha plume (Lima Neto, 1998b; Mizusaki et al., 2002).

The various timing relationships summarized in Fig. 4 provide an important framework to interpret our fission-track results. Importantly, it is prudent to bear in mind that there are several sources of heating (and therefore cooling) that could, in theory, be responsible for the observed results. For example, thermal effects 


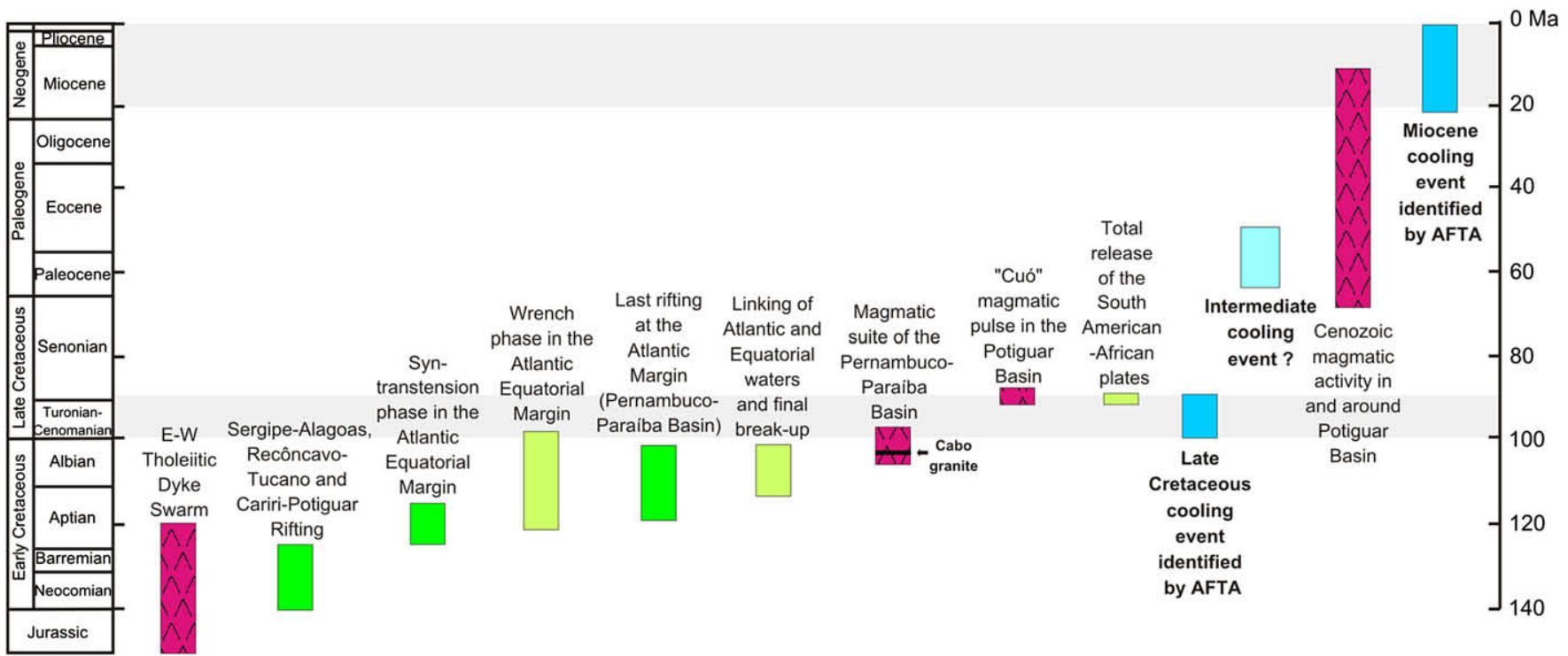

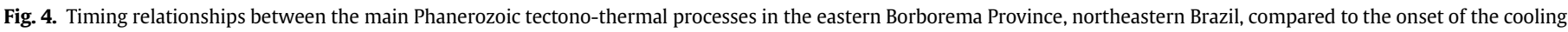

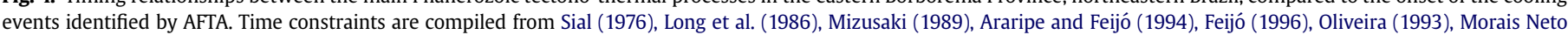
(1999), Matos (1999, 2000), Hegarty et al. (2002), Lima Filho and Szatmari (2002), Souza et al. (2004), Jardim de Sá et al. (2004), and Almeida et al. (2005).

related to rifting, post-rift tectonics, regional denudation, intrusive and extrusive magmatic activity, and localized hydrothermal fluid flow effects associated with all of these mechanisms can potentially have affected the Brazilian margin and adjacent interior. The sampling strategy adopted was designed such that the dominant heating or cooling effects on the Borborema Plateau area could be directly measured as opposed to being assumed or inferred from various basin models or crustal deformation schemes.

\section{Sampling details and background}

Fission-track samples were collected along two regional transects across the Borborema Plateau (Figs. 5 and 6).

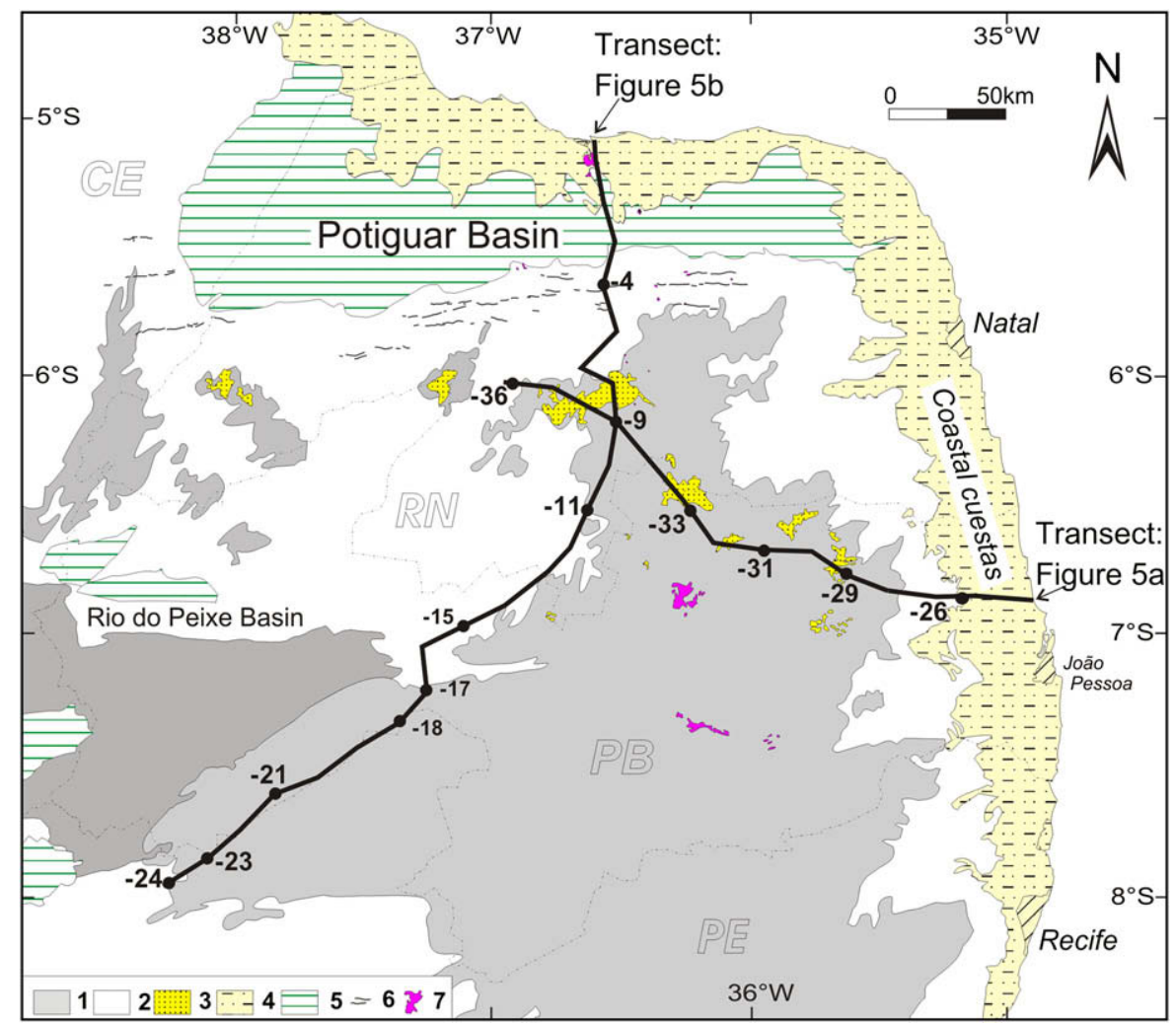

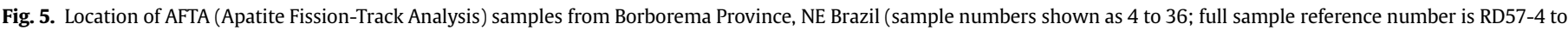

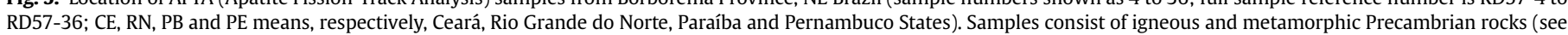

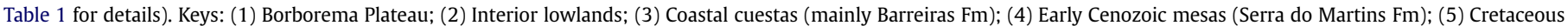
basins; (6) Early Cretaceous Tholeiitic Dike Swarm; (7) Cenozoic volcanics. 
a

E-W Transect

E-SE

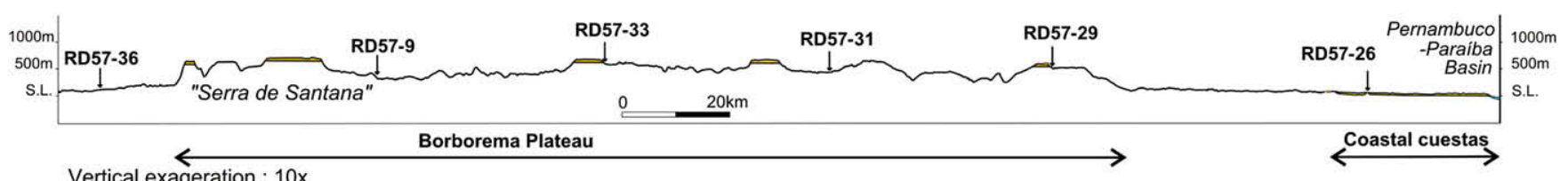

N-S Transect

b
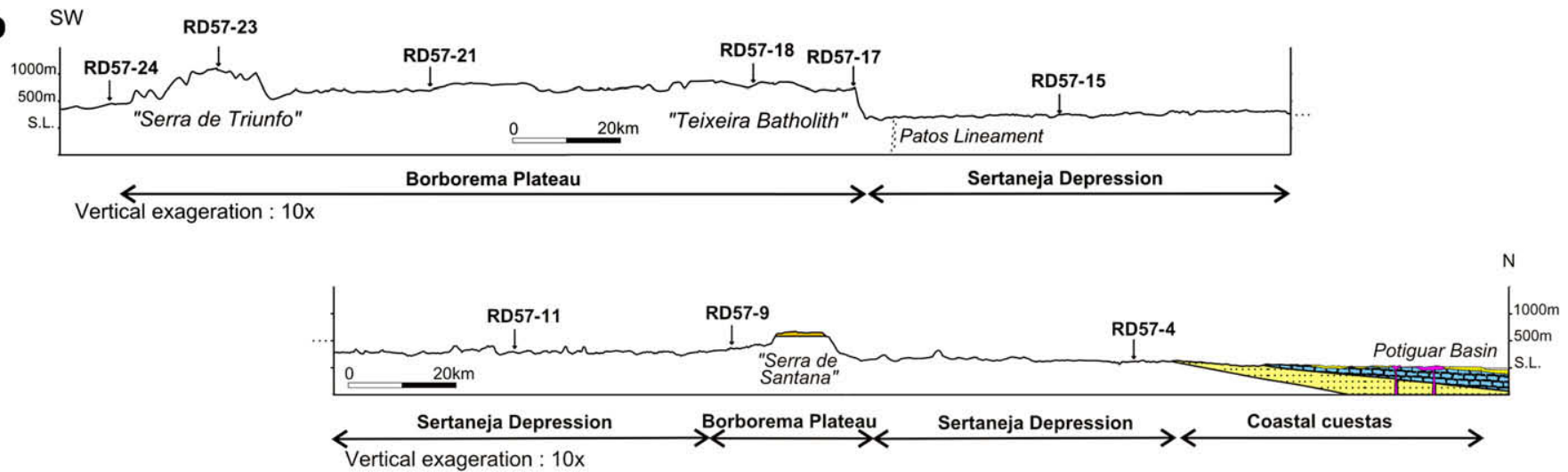

Fig. 6. Regional topographic sections showing the location of selected samples: (a) East-West transect; (b) North-South transect.

Fourteen crystalline basement samples were selected for fission-track analysis, representing a broad range in rock type, age and elevation (see Table 1). They represent Precambrian igneous and metamorphic rocks from various geological domains comprising the region (Table 1). The samples were selected to provide a good spread across the study area, so as to reveal any real variation in thermal history across distinct domains of the Borborema Province. With these constraints, we can evaluate the timing and mechanisms responsible for the regional topographic development of the Borborema region, as well as related issues, such as denudation and sediment supply to the offshore and evolution of the adjacent passive margin.

\section{Recovering thermal histories from fission-track data}

\subsection{Basis of fission-track technology}

Following evidence in the 1970s and 1980s (Gleadow et al., 1983) that the length of fission tracks in detrital grains of apatite alters in response to temperature and time, the fission-track "dating" technique was rapidly understood to be less reliable as a geochronological tool, but hugely exciting as a potential thermochronometer. Although there have been significant advances in this technology since that time, the fundamental basis of the technique remains the same. The interpretation of thermal history

Table 1

Sample details and apatite yields from the Borborema Province, NE Brazil

\begin{tabular}{|c|c|c|c|c|c|c|}
\hline Geotrack sample number RD57 & Field number $^{\mathrm{a}}$ & Rock-type & Formation or locality & Stratigraphic age & Chronologic age $(\sim \mathrm{Ma})$ & Apatite yield $^{\mathrm{b}}(\mathrm{ng}, \mathrm{nl})$ \\
\hline \multicolumn{7}{|l|}{ North-South transect } \\
\hline 4 & DS10-RN & Granite & Angicos (RN) & Neoproterozoic & $>550$ & Excellent \\
\hline $9^{c}$ & PB9-RN & Orthogneiss & Currais Novos (RN) & Neoproterozoic & $>550$ & Excellent \\
\hline 11 & DS7-RN & Granite & Acari batholit (RN) & Neoproterozoic & $>550$ & Excellent \\
\hline 15 & DS3-PB & Migmatite & São Mamede (PB) & Paleoproterozoic & $>550$ & Excellent \\
\hline 17 & PB7-PB & Granite & Teixeira batholit (PB) & Neoproterozoic & $>550$ & Excellent \\
\hline 18 & PB6-PB & Granite & Teixeira batholit (PB) & Neoproterozoic & $>550$ & Excellent \\
\hline 21 & PB3-PB & Granite & Teixeira batholit (PB) & Neoproterozoic & $>550$ & Excellent \\
\hline 23 & PB1-PE & Sienite & Triunfo (PE) & Neoproterozoic & $>550$ & Excellent \\
\hline 24 & DS1-PE & Gneiss & Serra Talhada (PE) & Neoproterozoic & $>550$ & Excellent \\
\hline \multicolumn{7}{|l|}{ East-West transect } \\
\hline 26 & TC1-PB & Granite & Mamanguape (PB) & Neoproterozoic & $\sim 550$ & Excellent \\
\hline 29 & PB14-PB & Granite & Solânea mesa (PB) & Neoproterozoic & $>550$ & Excellent \\
\hline 31 & PB12-PB & Gneiss & Barra de Santa Rosa (PB) & Paleoproterozoic & $>550$ & Excellent \\
\hline 33 & PB10-PB & Gneiss & Cuité mesa (PB) & Paleoproterozoic & $>550$ & Excellent \\
\hline $9^{c}$ & PB9-RN & Orthogneiss & Currais Novos (RN) & Neoproterozoic & $>550$ & Excellent \\
\hline 36 & DS11-RN & Granite & Jucurutu (RN) & Neoproterozoic & $>550$ & Excellent \\
\hline
\end{tabular}

a The samples were labeled in accordance with the geomorphological domains and to its regional location: XXnn-YY, where XX = BP (Potiguar Basin), DS ("Sertaneja" Depression), PB (Borborema Plateau) and TC (Coastal Plains); YY = PB (Paraíba State), RN (Rio Grande do Norte State) and PE (Pernambuco State).

b Yield based on quantity of apatite suitable for age determination. Excellent: $>20$ grains; very good: $\sim 20$ grains; fair: $10-15$ grains; very poor: $<5$ grains.

c Sample location intersects both transects. All samples were collected from surface outcrops. 
from fission-track data is based on the annealing or shortening of spontaneous fission tracks in uranium-bearing minerals. Fission tracks, observed in apatite, sphene and zircon, for example, were described by Fleischer et al. (1975) as narrow paths or finite trails of intense damage in a crystal lattice that form by the natural fission of ${ }^{238} \mathrm{U}$. These linear zones of damage, called fission tracks, are made visible under an ordinary light microscope using an etching agent that preferentially attacks the damaged zone. In mineral and hydrocarbon exploration, fission-track behavior in apatite has the advantage over other minerals by providing quantitative information about the upper few kilometers of the crust. As apatite is a common constituent of most sandstones and plutonic rocks, the technique has broad and often powerful applications in geological studies, providing quantitative constraint on the thermal history of a sample from surface to $\sim 145^{\circ} \mathrm{C}$.

The repair of the fission-track damage commences preferentially at the tips of the tracks at low temperatures, progressing until maximum temperature is reached, at which time the annealed length of the track is "frozen" or erased entirely if total annealing has occurred. The fission-track age is also reduced as a result of the track length reduction due to the reduced probability of tracks intersecting the polished surface. Thus, the fission-track age becomes a parameter with no fundamental meaning in its own right, but must be interpreted together with the track length data to provide thermal history information. Total erasure of tracks occurs at $\sim 95-145^{\circ} \mathrm{C}$, depending on the chemical composition (specifically the chlorine content $[\mathrm{Cl}]$ ) of the apatite grain, such that higher- $\mathrm{Cl}$ grains retain tracks at higher temperature than low- $\mathrm{Cl}$ grains. Thus if the effect of $\mathrm{Cl}$ content is not included in an interpretation or the analysis, an error of as much as $50{ }^{\circ} \mathrm{C}$ (equivalent to perhaps $2000 \mathrm{~m}$ of denudation) may affect the fission-track thermal history solution.

Tracks form constantly through time with a uniform length ( $\sim 15-16 \mu \mathrm{m}$ in apatite), visible through etching, and anneal according to their time-temperature history. In this sense, each track records a different proportion of the total thermal history of the grain or rock, with older tracks experiencing more of the history than younger tracks within the same grain. Therefore in theory, the collective information available from all tracks in apatite in a rock sample allow an assessment of the complete thermal history of the sample, in some cases retaining information about the thermal history of the provenance terrain(s). This memory of the predepositional thermal history in sedimentary rocks is referred to as inheritance, and must be taken into account in the interpretation of fission-track data.

The first step in recovering the thermal history of a sample is data acquisition, followed by iterative forward modeling of fissiontrack parameters. Data acquisition consists of three measurements from each analyzed grain in a sample mount: (1) the number of fission tracks (i.e. density of tracks), (2) the length of horizontal confined tracks (i.e. track length distribution within a sample), and (3) the chlorine composition. The original basis of this approach, based on age and length data only, is described in several key publications (Gleadow et al., 1986; Laslett et al., 1987; Green et al., 1989a), which have served as the basis for most fission-track application studies in the last 20 years (Gallagher et al., 1998; Issler et al., 1999; Gleadow et al., 2002; Osadetz et al., 2002; Lim et al., 2003; Stockli et al., 2003).

The second step is forward modeling fission-track parameters, by inputting nominated time-temperature histories into a kinetic model, and comparing predicted and measured parameters until an appropriate match is found. Most application studies rely on the kinetic description of Laslett et al. (1987) for generating thermal history interpretations from fission-track data. This model is well documented for mono-compositional or mono-kinetic apatites (e.g. Green et al., 1989b), based on a series of laboratory experiments on Durango apatite (Green et al., 1986; Laslett et al., 1987; Duddy et al., 1988), which is representative of a single compositional group, i.e. $0.45 \mathrm{wt} \% \mathrm{Cl}$. Laslett et al. (1987) targeted their attentions to a single compositional group, having recognized that $\mathrm{Cl}$ was a factor in the annealing process. It is now widely accepted that this kinetic description is inappropriate to all but one compositional group.

Early publications (Green et al., 1986) made reference to the influence of $\mathrm{Cl}$ content on annealing, but it was not until the 1990s that exhaustive investigations were undertaken to describe this behavior quantitatively (Green et al., 1996). All solutions here are based on apatite fission-track analysis (AFTA; Green et al., 1996), in which compositional influences are included in both the measured

Table 2

Apatite fission-track analytical results for outcropping samples from the Borborema Province, NE Brazil

\begin{tabular}{|c|c|c|c|c|c|c|c|c|c|c|c|c|}
\hline $\begin{array}{l}\text { Geotrack } \\
\text { sample } \\
\text { number }\end{array}$ & $\begin{array}{l}\text { Elevation } \\
(\mathrm{m})\end{array}$ & $\begin{array}{l}\text { Number } \\
\text { of age } \\
\text { grains }\end{array}$ & $\rho_{\mathrm{D}}$ & $\rho_{\mathrm{S}}$ & $\rho_{\mathrm{I}}$ & $\begin{array}{l}\text { Uranium } \\
\text { content } \\
\text { (ppm) }\end{array}$ & $\begin{array}{l}\mathrm{P}\left(\chi^{2}\right) \\
(\%)\end{array}$ & $\begin{array}{l}\text { Composition } \\
\text { Mean (Max- } \\
\text { Min) }(\mathrm{wt} \% \mathrm{Cl})\end{array}$ & 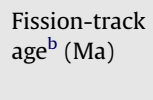 & $\begin{array}{l}\text { Number of } \\
\text { lengths } \\
\text { (n) }\end{array}$ & $\begin{array}{l}\text { Mean track } \\
\text { length } \\
(\mathrm{mm})\end{array}$ & $\begin{array}{l}\text { Standard } \\
\text { Deviation } \\
(\mathrm{mm})\end{array}$ \\
\hline \multicolumn{13}{|c|}{ North-South transect } \\
\hline RD57-4 & 123.9 & 20 & $1.373(2166)$ & $0.904(401)$ & 2.495 (1107) & 20.7 & 0.9 & $0.17(0.00-0.35)$ & $98.9 \pm 8.4$ & 102 & $12.22 \pm 0.20$ & 2.01 \\
\hline RD57-9a & 367.5 & 20 & $1.368(2166)$ & $0.704(296)$ & $1.855(780)$ & 15.5 & 0.0 & $0.02(0.00-0.04)$ & $102.1 \pm 13.1$ & 108 & $11.80 \pm 0.22$ & 2.24 \\
\hline RD57-11 & 279.1 & 20 & $1.366(2166)$ & $1.849(1464)$ & $4.386(3472)$ & 36.6 & 0.0 & $0.01(0.00-0.03)$ & $108.5 \pm 7.1$ & 11 & $12.19 \pm 0.18$ & 1.81 \\
\hline RD57-15 & 280.8 & 20 & $1.364(2166)$ & $1.755(1361)$ & 4.560 & 38.1 & 0.0 & $0.07(0.00-0.13)$ & $102.0 \pm 6.2$ & 107 & $12.02 \pm 0.18$ & 1.90 \\
\hline RD57-17 & 722.2 & 21 & $1.361(2166)$ & $0.354(163)$ & 1.102 (507) & 9.2 & 2.2 & $0.00(0.02-0.04)$ & $93.6 \pm 12.0$ & 104 & $12.26 \pm 0.24$ & 2.45 \\
\hline RD57-18 & 770.7 & 20 & $1.247(2030)$ & $0.746(405)$ & $2.427(1318)$ & 22.2 & 1.8 & $0.04(0.00-0.08)$ & $71.1 \pm 5.9$ & 63 & $12.36 \pm 0.14$ & 1.09 \\
\hline RD57-21 & 691.8 & 20 & $1.254(2030)$ & $0.408(208)$ & $1.179(600)$ & 10.7 & 44.4 & $0.01(0.00-0.02)$ & $82.2 \pm 7.0$ & 100 & $12.07 \pm 0.13$ & 1.33 \\
\hline RD57-23 & 1075.2 & 20 & $1.261(2030)$ & $0.085(93)$ & $0.117(127)$ & 1.1 & 51.3 & $0.01(0.00-003)$ & $173.3 \pm 24.1$ & 12 & $13.16 \pm 0.37$ & 1.27 \\
\hline RD57-24 & 475.0 & 20 & 1.269 (2030) & $0.558(334)$ & $1.081(646)$ & 9.7 & 16.1 & $0.02(0.00-0.04)$ & $123.5 \pm 9.0$ & 101 & $12.32 \pm 0.17$ & 1.73 \\
\hline \multicolumn{13}{|c|}{ East-West transect } \\
\hline RD57-26 & 19.1 & 20 & $1.276(2030)$ & 1.467 (1089) & $3.684(2736)$ & 32.9 & 0.0 & $0.02(0.00-0.04)$ & $97.2 \pm 8.2$ & 102 & $12.53 \pm 0.11$ & 1.13 \\
\hline RD57-29 & 524.1 & 20 & 1.219 (1922) & $0.623(283)$ & $1.964(891)$ & 18.4 & 0.2 & $0.02(0.00-0.04)$ & $66.8 \pm 8.1$ & 115 & $12.40 \pm 0.18$ & 1.89 \\
\hline RD57-31 & 435.7 & 21 & 1222 (1922) & $0.201(196)$ & $0.925(900)$ & 8.6 & 30.0 & $0.02(0.00-0.04)$ & $52.1 \pm 4.4$ & 102 & $12.58 \pm 0.17$ & 1.67 \\
\hline RD57-33 & 616.2 & 20 & $1.224(1922)$ & $1.353(900)$ & 3.613 (2403) & 33.6 & 0.0 & $0.04(0.00-0.08)$ & $85.9 \pm 6.8$ & 111 & $13.02 \pm 0.13$ & 1.36 \\
\hline RD57-9 $9^{a}$ & 367.5 & 20 & $1.368(2166)$ & $0.704(296)$ & $1.855(780)$ & 15.5 & 0.0 & $0.02(0.00-0.04)$ & $102.1 \pm 13.1$ & 108 & $11.80 \pm 0.22$ & 2.24 \\
\hline RD57-36 & 107.3 & 20 & 1.230 (1922) & $1.291(824)$ & 3.083 (1967) & 28.6 & 1.2 & $0.11(0.00-0.22)$ & $97.3 \pm 6.6$ & 106 & $12.01 \pm 0.17$ & 1.76 \\
\hline
\end{tabular}

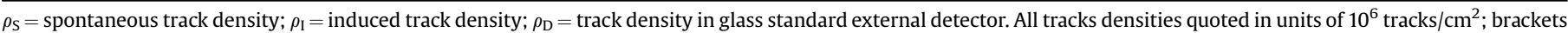
show number of tracks counted. Values of $\rho_{\mathrm{D}}$ and $\rho_{\mathrm{I}}$ measured in mica external detectors; $\rho_{\mathrm{S}}$ measured in internal surfaces.

a Sample location intersects both transects.

b Central age - used where sample contains a significant spread of single grain ages $\left(P\left(\chi^{2}\right)<5 \%\right)$ - otherwise pooled age shown. Errors quoted at $\pm 1 \sigma$. Ages calculated using

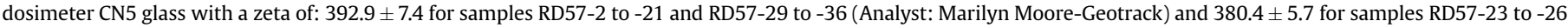
(Analyst: Chris O’Brien-Geotrack). 
data and kinetic algorithm. By introducing systematically varying heating and cooling events into the initial estimate of the timetemperature history, predicted fission-track parameters are compared to the measured parameters (age and length) in the relevant compositional groupings until an acceptable match to the measured values is identified, thus placing limits on the thermal history for the sample. One- and two-event models are routinely run for each sample with assumed heating and cooling rates of $1{ }^{\circ} \mathrm{C} / \mathrm{Ma}$ and $10^{\circ} \mathrm{C} / \mathrm{Ma}$, respectively. In some cases, both the oneand two-event models provided a satisfactory fit to the data, but in most cases the data could only be satisfied by a two-event model. Solutions are reported in the form of $95 \%$ confidence limits (Table 2 ) that define the range of times from which cooling commenced in relation to each episode and the corresponding range in the value or range of the maximum/peak paleotemperature.

\subsection{Thermal history solutions: examples, sensitivities and assumptions}

It is important to understand what is meant by thermal history in this context, and the underlying assumptions that comprise a solution derived from fission-track data. Firstly, fission-track thermal history solutions refer strictly to the time and magnitude of past heating events, and not to the complete thermal history, which would commonly be described as including the path to and from the maximum, or local maximum, paleotemperature. These variables, heating and cooling rates, are in fact assumed as described previously.

Although sometimes referred to as constraining a "heating" event, the fission-track record strictly captures only the time at which the sample begins to "cool" from maximum or peak paleotemperature. Often a reliable solution from a single sample will give constraint on two, sometimes three, thermal events, but only if the more recent events are cooler than the earlier events. Fission-track data cannot be used to constrain cooler, older events, because the track information will be effectively overprinted by the effects of the relatively hotter, younger event(s).

A detailed inspection of a typical thermal history solution in this study will help to underscore the strengths and limitations of the results. As an example, we use results from sample RD57-36 (Brasiliano granite collected in the "Sertaneja Depression", near Jucurutu village), which is representative of the data set. The bestfit two-event thermal history solution is shown in Fig. 7, and corresponds to the solution reported in Table 3 . The solution indicates the sample cooled through $100{ }^{\circ} \mathrm{C}$ sometime between 110 and $70 \mathrm{Ma}$, and was affected by a second event, with cooling from maximum paleotemperatures of $70-60{ }^{\circ} \mathrm{C}$ beginning sometime in the last $15 \mathrm{Ma}$. The solution provides unequivocal evidence for paleo-heating (limited by the maximum paleotemperature) and, furthermore, gives good definition to the timing and magnitude of multiple events. However, there are several elements of the thermal history which fission-track data cannot constrain: (1) the paleotemperature during the interval between the two events (shown by the dotted line, Fig. 7a); (2) the maximum allowable value of paleotemperature associated with the first event, and (3) the thermal history prior to the first event. The measured track length for this sample (dark grey) compared to the prediction for the best-fit solution (light grey) is shown in Fig. 7b; for this model, a one-event solution did not provide a satisfactory fit to the data.

The quality of each solution and sensitivity are judged by many factors, including the quality of the measured data, the $\mathrm{Cl}$ range represented in the sample and the fit between measured and predicted parameters. The age versus $\mathrm{Cl}$ relationship predicted by the best-fit solution given (Fig. 7) is shown in Fig. 8. The measured single grain ages are plotted with respect to $\mathrm{Cl}$ composition (wt\% $\mathrm{Cl}$ ), with the predicted relationship, based on this thermal history,
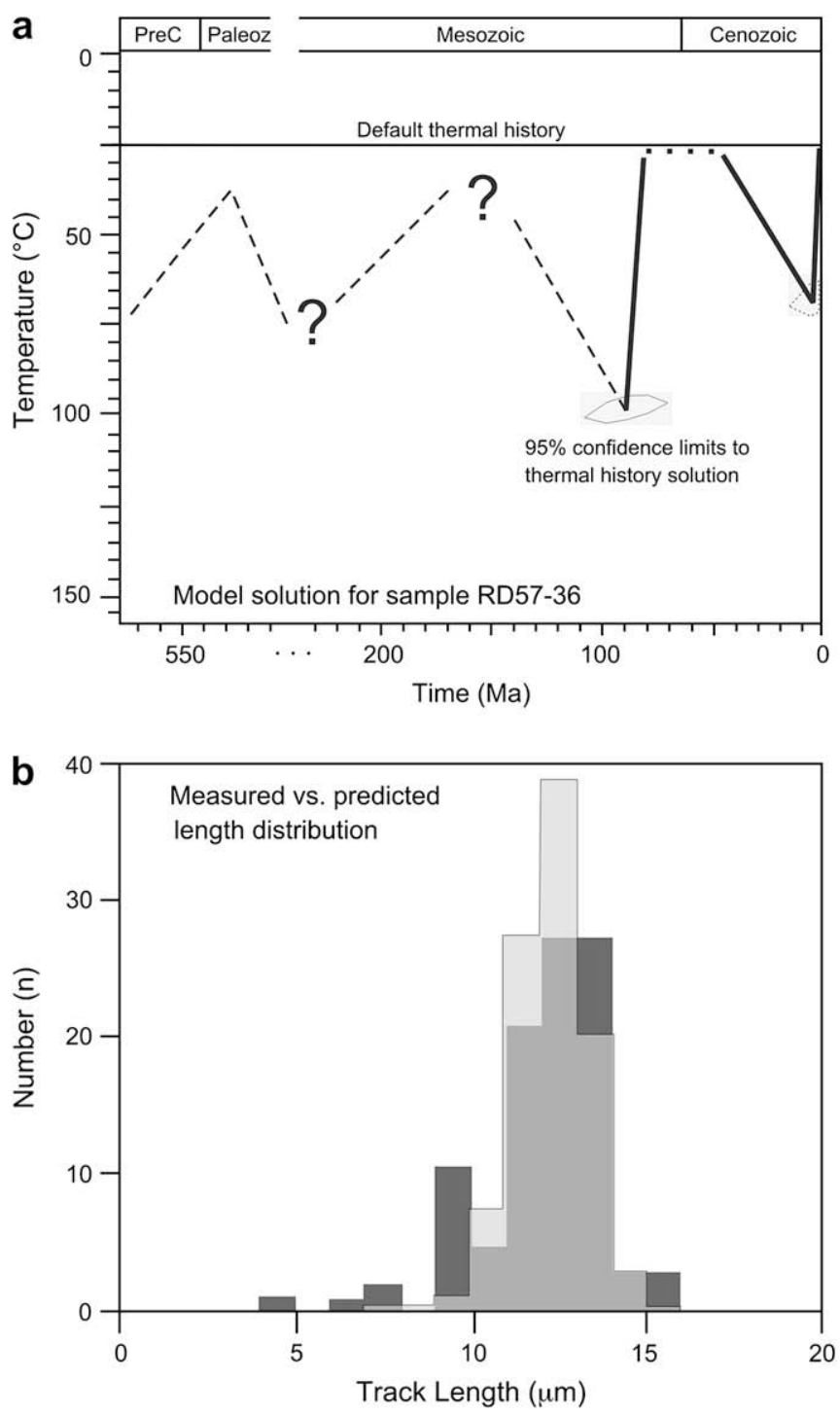

Fig. 7. (a) Thermal history solution for fission-track sample RD57-36 (reported in Table 3). According to the modeling results, two paleothermal episodes are required, with each episode described by the allowable range in time and temperature that can account for the measured fission-track ages and lengths in this sample; the complete thermal history of the sample cannot be extracted as indicated (dotted line) nor the history prior to the first recognized cooling event. (b) Comparison between measured track lengths (dark grey) and length predictions (light grey) corresponding to the bestfit thermal solution shown in (a); intermediate tone represents the overlap.

plotted as a solid line. The history provides a good fit to the data overall, although there are two grains (circled) that lie outside the predicted trends. The apparent scatter in ages within the low-Cl group (0.0-0.1 wt\% $\mathrm{Cl}$ ) is typical of this compositional group, but all grains in this group except one, satisfy the preferred history. The measured age of this grain is notably quite precise and may represent an unusually sensitive grain (perhaps reacting to Neogene volcanism or an anomalous local heat flow?) or is contaminated. The slightly older grain in the $0.1-0.2 \mathrm{wt} \% \mathrm{Cl}$ group lies outside the predicted value.

Predictions from three other thermal histories shown in Fig. 8 illustrate the degree of sensitivity of the fission-track technique. Two examples are shown in which the timing of the first event is placed earlier in the history by 50 and $110 \mathrm{Ma}$ compared to the best-fit history. As shown, the predicted age versus $\mathrm{Cl}$ relationships from these histories do not satisfy the measured ages in the sample, and therefore those histories can be discarded. In the third 
Table 3

Summary of thermal history results for outcropping AFTA samples from Borborema Province, NE Brazil

\begin{tabular}{|c|c|c|c|c|c|c|}
\hline \multirow{3}{*}{$\begin{array}{l}\text { Geotrack sample } \\
\text { number RD57 }\end{array}$} & \multirow{3}{*}{$\begin{array}{l}\text { Stratigraphic or } \\
\text { absolute age }(\sim \mathrm{Ma})\end{array}$} & \multirow{3}{*}{$\begin{array}{l}\text { Present-day } \mathrm{t} \\
\text { emperature }\left({ }^{\circ} \mathrm{C}\right)\end{array}$} & \multicolumn{4}{|l|}{ Thermal history solution } \\
\hline & & & \multicolumn{2}{|l|}{ First episode } & \multicolumn{2}{|l|}{ Second episode } \\
\hline & & & Maximum paleotemperature $\left({ }^{\circ} \mathrm{C}\right)$ & $\begin{array}{l}\text { Onset of } \\
\text { cooling (Ma) }\end{array}$ & Maximum paleotemperature $\left({ }^{\circ} \mathrm{C}\right)$ & $\begin{array}{l}\text { Onset of } \\
\text { cooling (Ma) }\end{array}$ \\
\hline \multicolumn{7}{|c|}{ North-South transect } \\
\hline $4+$ & $>550$ & 25 & $100-105$ & $120-55$ & $65-80$ & $35-8$ \\
\hline $9^{a}+$ & $>550$ & 25 & 95-105 & $100-55$ & $55-70$ & $20-0$ \\
\hline $11+$ & $>550$ & 25 & $95-105$ & $135-90$ & $65-75$ & $32-2$ \\
\hline $15+$ & $>550$ & 25 & $90-100$ & $105-55$ & $60-75$ & $25-0$ \\
\hline $17+$ & $>550$ & 25 & $95-105$ & $90-45$ & $60-80$ & $40-12$ \\
\hline $18+$ & $>550$ & 25 & $>100$ & $105-70$ & $65-80$ & $15-0$ \\
\hline $21+$ & $>550$ & 25 & $80-95$ & $87-27$ & $60-75$ & $10-0$ \\
\hline 23 & $>550$ & 25 & $>100$ & $280-100$ & $50-85$ & $180-0$ \\
\hline $24+$ & $>550$ & 25 & $90-100$ & $140-80$ & $55-70$ & $35-0$ \\
\hline \multicolumn{7}{|l|}{ East-West transect } \\
\hline $26+$ & $>550$ & 25 & $>105$ & $125-95$ & $65-75$ & $15-0$ \\
\hline $29+$ & $>550$ & 25 & $90-105$ & $85-50$ & $55-75$ & $30-0$ \\
\hline $31+$ & $>550$ & 25 & $100-105$ & $65-30$ & $55-75$ & $25-0$ \\
\hline 33 & $>550$ & 25 & $80-100$ & $100-65$ & $30-65$ & $27-0$ \\
\hline $9^{a}+$ & $>550$ & 25 & $95-105$ & $100-55$ & $55-70$ & $20-0$ \\
\hline $36+$ & $>550$ & 25 & $95-100$ & $110-70$ & $60-70$ & $15-0$ \\
\hline
\end{tabular}

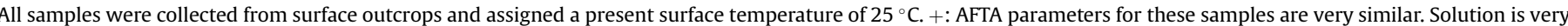

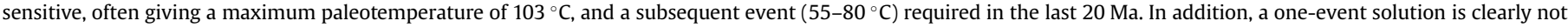
allowed.

a Sample location intersects both transects.

example, if we modify the best-fit history decreasing the maximum paleotemperature by $10^{\circ} \mathrm{C}$ (from 100 to $90^{\circ} \mathrm{C}$ during the first of event), the model significantly over-predicts the ages in each compositional group. Although only a limited range in composition

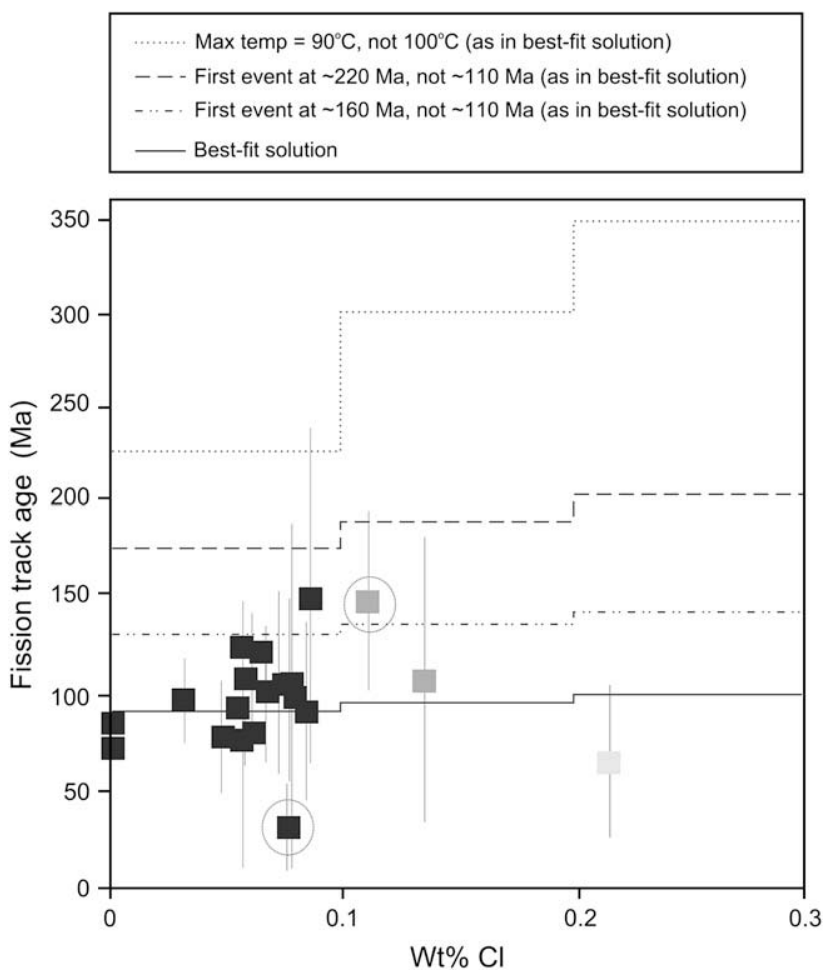

Fig. 8. Measured single grain FT ages in sample RD57-36 plotted against the chlorine content $(\mathrm{Cl})$ of each grain. Predicted age- $\mathrm{Cl}$ relationships are generated from the bestfit solution, shown in Fig. 7, as well as three alternate models, which do not satisfy the measured parameters. These alternate histories involving adjustments in both time and temperature can be excluded as viable histories for this sample. Note the important influence that the high- $\mathrm{Cl}$ grain offers on resolving the timing of maximum temperature, such that cooling from $100{ }^{\circ} \mathrm{C}$ anytime earlier than $130 \mathrm{Ma}$ can be excluded. is represented in this sample $(0.0-0.3 \mathrm{wt} \% \mathrm{Cl})$, Fig. 8 demonstrates the necessity and utility of using compositional control not only to improve resolution of the thermal history, but also to identify outliers that may represent real effects or contamination.

Modeling procedures introduce ever-varying time-temperature conditions as part of imposed one- and two-event models until predicted parameters match measured values, and limits to the thermal history are defined. Sometimes one- and two-event models cannot be distinguished, in which case the solution, as reported in Table 3, is broader so as to include all possible combinations of time and temperature that satisfy the data. The aim in using fission-track data in this way is to quantitatively characterize those periods of elevated temperature in terms of time of cooling and magnitude of heating, and to recognize the limitations of each solution.

\subsection{Thermal history of the Borborema Plateau - analyses and solutions}

In Table 2, analytical data for each fission-track sample from the study area are reported. Note the reported fission-track ages refer to a mean value for the sample, without reference to individual single grain ages characterizing the sample (in the interest of space). The measured fission-track ages vary between $\sim 50$ and $170 \mathrm{Ma}$, although most of the measured fission-track ages lie within a much tighter interval, between 70 and $100 \mathrm{Ma}$ (note, we emphasis that the measured mean ages should be considered only as a measured parameter and not used directly to infer the timing of events). Chlorine contents in the sample suite are dominated by the $0.0-0.1 \mathrm{wt} \% \mathrm{Cl}$ group, but a large proportion of grains have chlorine contents ranging from 0.1 to $0.4 \mathrm{wt} \% \mathrm{Cl}$. Mean track lengths for the sample suite (Table 2) vary between 11.67 and $13.16 \mu \mathrm{m}$. The number of confined tracks in each sample generally exceeds 50, while the number of age grains in each sample is typically 20 or more. The data quality of the vast majority of samples in this study is considered excellent.

The thermal history solutions for each of the 14 samples (Table 3 ) show evidence for paleo-heating and consistency, suggesting some uniformity in the history across this broad and complex 
region. Analytical results from all Precambrian samples RD57-4, -9, $-15,-17,-18,-21,-24,-26,-29,-33$ and -36 are remarkably similar (Fig. 9). Solutions for these samples typically show evidence of Cretaceous cooling from maximum paleotemperatures between 95 and $105{ }^{\circ} \mathrm{C}$ and a subsequent event in the last $20 \mathrm{Ma}$, associated with maximum paleotemperatures of $60-80^{\circ} \mathrm{C}$ (Table 3 ). In other hand, samples RD57-17, -21, -29 and -31 suggest an intermediate cooling event may also have occurred in the Late Cretaceous-Early Cenozoic transition.

Sample RD57-18, a Precambrian granite collected in the highlands of the Borborema Plateau (Teixeira batholith; Fig. 6b) gave a relatively young fission-track age $(71.1 \pm 5.9 \mathrm{Ma})$, which is in marked contrast to the older ages from samples located at similar altitudes on the same batholith, although the corresponding timing solution for the first event (105-70 Ma) is comparable to other solutions (Fig. 10). There is no significant occurrence of Late Cretaceous-Paleogene volcanism in this vicinity and so the implications of this relatively young age at this location remains uncertain.

Results from sample RD57-23, collected adjacent to one of the highest elevations of the region, show an unusual solution indicative of an older event, which lies slightly outside the main trend (Fig. 10). The corresponding fission-track age $(172.9 \pm 24.7 \mathrm{Ma})$ is the oldest in the data set, but the fission-track lengths are limited. Nevertheless, the solution for this sample suggests cooling commenced some time between 280 and $100 \mathrm{Ma}$ and a second event in the last $170 \mathrm{Ma}$. In this case, the data can be accounted for by a single event, which could be interpreted as a continuous uplift/ cooling of the Triunfo batholith.

Timing constraints offered by each fission-track sample are plotted with respect to each other in Fig. 10, along the N-S and E-W transect. Across the region, there are no obvious trends in the timing control, which might suggest systematic variation or progression of events. Equally, we cannot discount the possibility of real variation within localized portions of the study area due to distinct evolution between different tectonic domains, as Phanerozoic reactivation of old structures among adjacent blocks are reported elsewhere in the Borborema Province (Destro et al., 1994; Nóbrega et al., 2005; Bezerra et al., 2008).

By evaluating the overlap in the timing constraints from each sample, the timing of these proposed synchronous events can be further refined. Results from most samples are consistent with a two-event model: Late Cretaceous (100-90 Ma) and Neogene (20-0 Ma). Intermediate events recorded by other samples reveal some added complexity to the generalized pattern of a two-event scenario for the region (Fig. 10).

For example, samples RD57-29 and -31, collected on the Precambrian crystalline massif yielded fission-track ages younger than the sample RD57-26 located on the coastal lowlands adjacent to the Paraíba sub-basin (Figs. 6a and 9). The solutions for the latter suggest cooling could have commenced early in Early Cretaceous $(\sim 125 \mathrm{Ma})$ in the coastal area, while at the eastern border of the Borborema Plateau, cooling commenced only by Late CretaceousEarly Paleogene, some $50 \mathrm{Ma}$ later. However, the fact that the timing limits from most solutions coincide in time (overlap in solutions is shown in Fig. 10) suggests that the recognized events may be largely synchronous across the region.

The thermal history solutions presented here are based on single sample interpretations, independent of the knowledge of the regional geology, basin models or results from neighbouring samples. In summary, the majority of data from both transects show evidence for the following:

i. The most profound conclusion of this work is the degree of paleo-heating required and the strong uniformity of results across a very broad region. In general, a two-event scenario, involving Late Cretaceous and Neogene paleothermal events, accounts for the results.

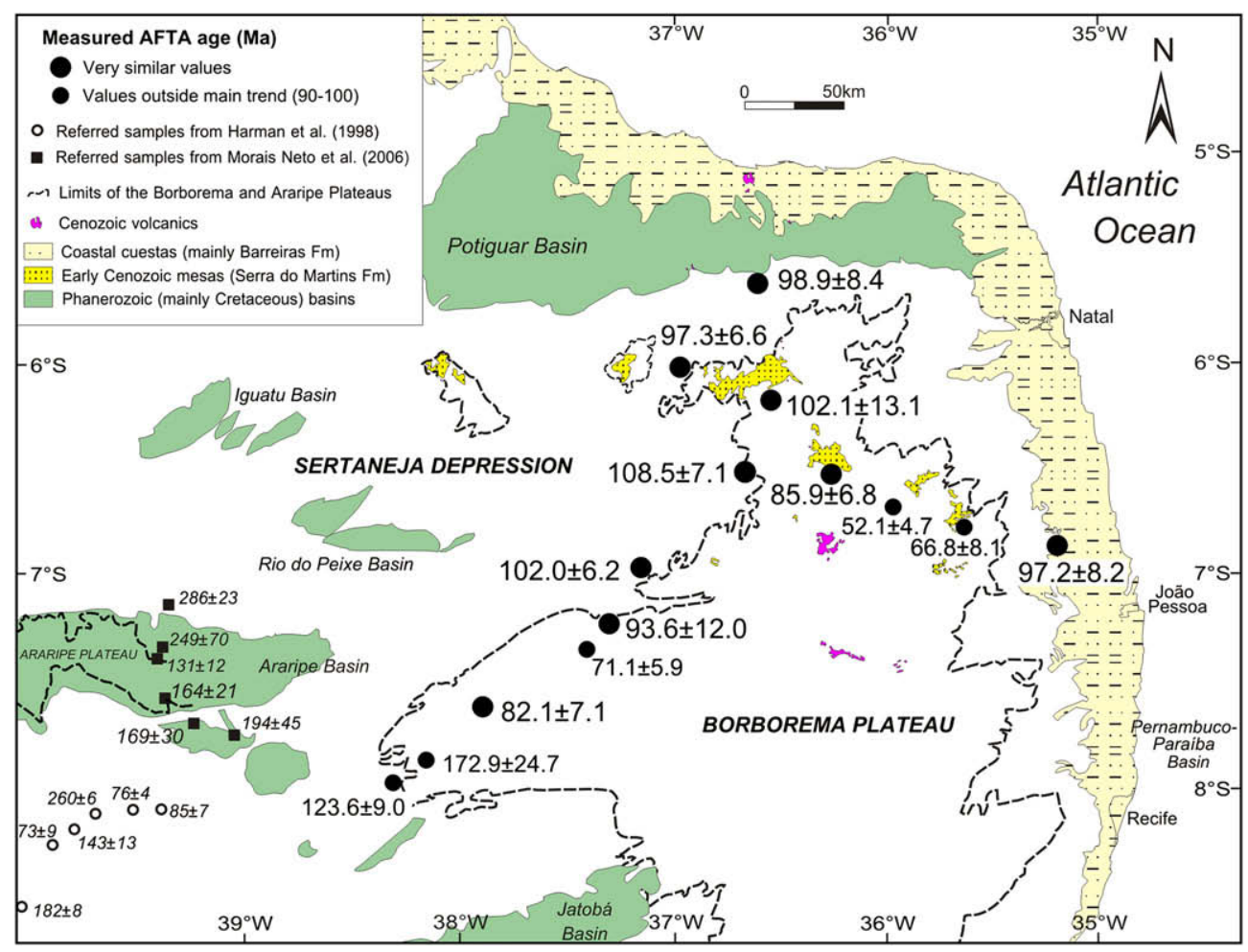

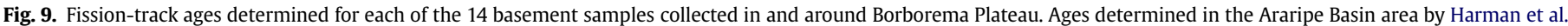
(1998) and Morais Neto et al. (2006) are quoted in italics. 


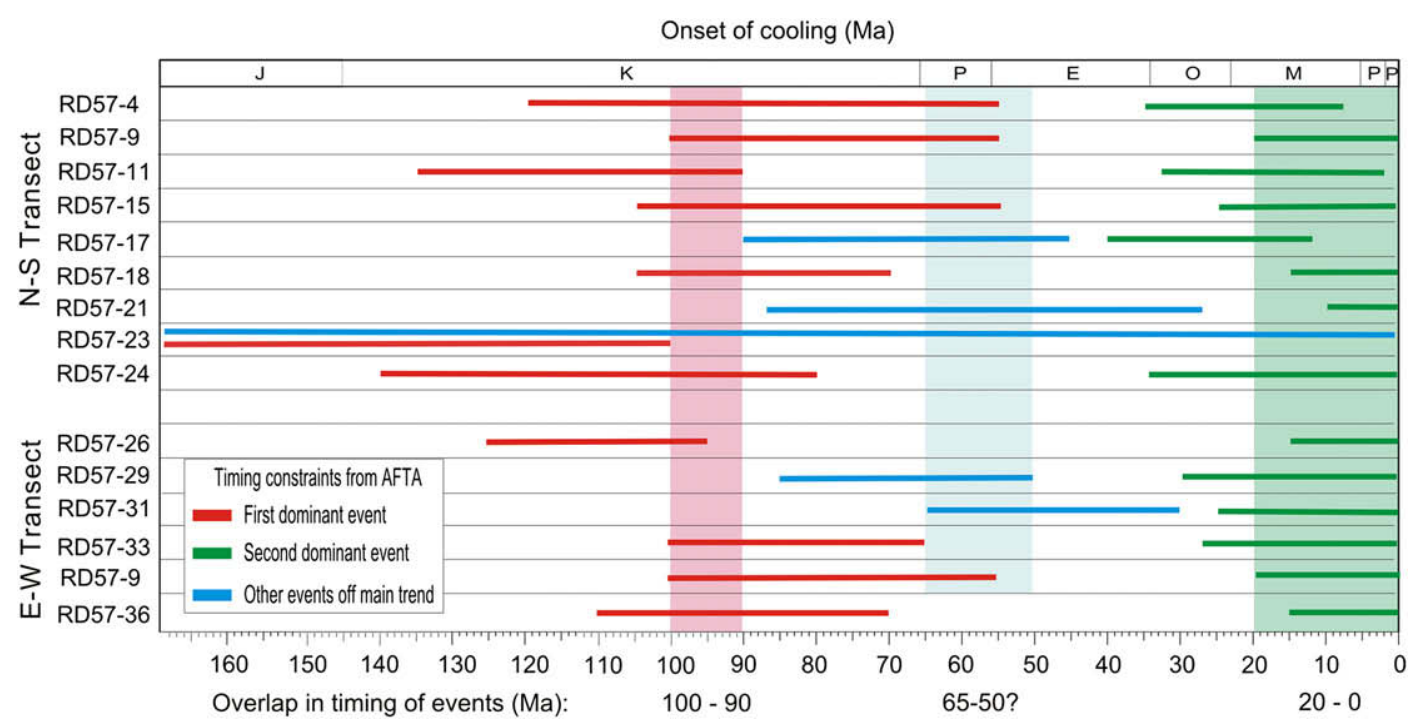

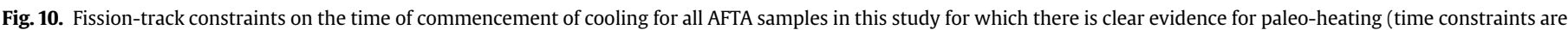

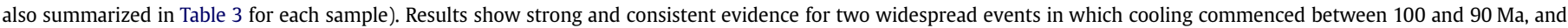

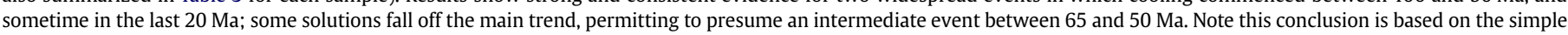

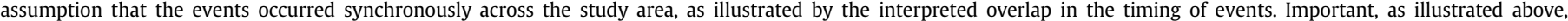
considerably more intra-plateau complexity would be allowed in the Borborema region if the assumption of synchronicity was not imposed.

ii. Other less dominating, intermediate event of PaleogeneEocene age is recorded in the region (samples RD57-17, -21, $-29,-31$ ), as well as the possibility of an older event is suggested by the sample RD57-23.

iii. It is not clear whether the main events can be represented as a single long-term cycle of continuous cooling, or if they represent discrete episodes of heating/cooling, in which basement was uplifted to or near the surface during the interval between the two events. If the recognized events are caused by paleo-burial, followed by erosion, the results demand kilometer-scale uplift and denudation of the crystalline basement, in the order of 1000-3000 m, since the mid Cretaceous breakup. Obviously, the estimate of erosion relies heavily on the assumed paleogeothermal gradient (and hence is associated with significant uncertainty, as different blocks may have been submitted to distinct thermal evolutions).

\section{Significance of the fission-track results}

Over the past few years there have been a number of fissiontrack studies from eastern Brazil (Gallagher et al., 1994; Karner et al., 1994; Hegarty et al., 1996; Harman et al., 1998; Hackspacher et al., 2004), none of which can be easily linked to topography generation and a causative tectonic event.

For example, Harman et al. (1998) in their study of the Guapore and São Francisco cratons show fission-track ages that range from 309-137 Ma to 260-76 Ma, respectively. They suggest that their fission-track results demonstrate two main pulses of denudational cooling: (1) the first beginning at $\sim 130 \mathrm{Ma}$, and (2) a younger episode of denudational cooling that began in the Late Cretaceous ( $\sim 80-60 \mathrm{Ma})$. While the authors attempt to relate the first event with the initial stages of breakup, our results indicate that fissiontrack age resetting is occurring uniformly over a vast geographic region, $200-400 \mathrm{~km}$ away from the sites of rifting. Harman et al. (1998) have invoked shear zone reactivation, synchronous with the Santonian events of central Africa, as a possible mechanism controlling their 80-60 Ma event (Late Cretaceous). It is extremely unlikely that localized shear zone reactivation can generate broadly distributed and relatively high (100s of meters) topographic relief across northeastern Brazil on a different plate than the observed Santonian inversion of central Africa (Guiraud and Bosworth, 1997).

The studies of both Gallagher et al. (1994) and Karner et al. (1994) show fission-track ages increasing with elevation towards the continental interior. This type of age profile is considered a "classic" response of rift flank denudation driven by slope retreat processes in which younger fission-track ages are at the base of the eroding escarpment and the older ages, reflecting minimal erosion/ cooling, are towards the crescent of the escarpment. The fissiontrack data in this study do not show this trend. In the Borborema Province, our derived thermal history solutions are somewhat similar across the entire study area, irrespective of rock type, stratigraphic age and elevation. We believe this response is best accounted for by regional denudation, but a component of higher heat flow cannot be ruled out, as various paleothermal events derived from fission-track analysis on the conjugate African margin (Bray et al., 2002) were in part controlled by elevated heat flow during the mid Cretaceous.

An active rift model, which in effect is a combination of plume dynamics with lithosphere extension, has long been hypothesized to drive the onset of rifting in northeastern Brazil (O'Connor and Duncan, 1990; Wilson, 1992; Lima Neto, 1998a; Thomaz Filho et al., 2000). Intracontinental rifting occurred in northeastern Brazil (e.g. the Rio do Peixe, Araripe and Iguatu Basins) between 140 and $118 \mathrm{Ma}$, and the amount of extension responsible for these interior basins was localized and minor $(\beta=1.1-1.2$; e.g. Magnavita et al., 1994). The minor extension led a number of authors to argue against the role of mantle plumes in triggering Early Cretaceous extension (e.g., Matos, 2000, 2001; Fairhead and Wilson, 2005). However, the broad zone of diffuse 145-125 Ma tholeiitic volcanism onshore (and younger volcanism offshore) northeastern Brazil, together with the restricted Late Albian volcanism in the Pernambuco-Paraíba Basin, requires a significant thermal anomaly within and large partial melting of the asthenosphere or mantle lithosphere.

Recently, Kusznir and Karner (2007) proposed that continental lithosphere thinning leading to breakup is controlled by an upwelling, divergent flow field that depending on the ascent velocity versus the divergent velocity, preferentially thins the lower continental crust and lithospheric mantle during extension. The 
mass balance to such extension thickens the adjacent hinterland crust and lithosphere over a width of 100s km away from the zone of breakup. For volcanic rifted margins, the horizontal flow velocity is slow compared with the vertical flow velocity and leads to a strain portioning within the crust and mantle exhumation in addition to lower crust and continental mantle thickening within the hinterland region (Fig. 11). According to this model, subsequent re-equilibration of the continental hinterland lithosphere geotherm generates uplift of 400-600 m over a timescale of 60-100 m.y. over distances of $400-600 \mathrm{~km}$. Uplift engendered by this upwelling, divergent flow field mechanism may represent a significant proportion of the post-breakup topography of the eastern onshore Brazilian margin.

The Late Aptian to Early Albian was a time of marine incursion in both the Potiguar and Araripe Basins (Araripe and Feijó, 1994; Ponte and Ponte Filho, 1990; Magnavita et al., 1994). The presence of Early to Middle Albian limestones (Santana Formation) now at elevations of $700-800 \mathrm{~m}$ in the Araripe Basin (the southernmost tip of the "Cariri-Potiguar Trend") is evidence for marine incursions into the interior of northeastern Brazil at this time. Further, the Late AptianEarly Albian shales of the Codó Formation drilled in the Paraíba Basin contains marine dinoflagellates of the genus Subtilisphaera (Antonioli and Arai, 2002) in addition to other marine fauna.

Considering that eustasy was higher by some $200 \mathrm{~m}$ in the early Late Cretaceous compared with the present (e.g., Bond and Kominz, 1988 ) then these observations require a $500-600 \mathrm{~m}$ epeirogenic uplift of the Borborema Province region sometime after the Late Albian. A similar conclusion was reached by Magnavita et al. (1994) for the Tucano and Jatobá Basins, and correlates with the 110$90 \mathrm{Ma}$ event defined by AFTA data for the Araripe area (Hegarty et al., 2002; Morais Neto et al., 2006). The magnitude of the post-rift uplift is not adequately explained by flexural deformation induced by sediment loading at the adjacent margin (Peulvast et al., 2008), as the expected topography generated by such mechanism is generally 100-200 $\mathrm{m}$ in amplitude.

Fig. 4 shows the temporal relationship between the cooling events identified by fission track in this study and various relevant tectonic activities in Borborema Province and adjacent regions. The first event (100-90 Ma) broadly correlates with erosive events in the marginal basins. In the Pernambuco-Paraíba basin, south of Recife, stratigraphic relationships on the breakup unconformity

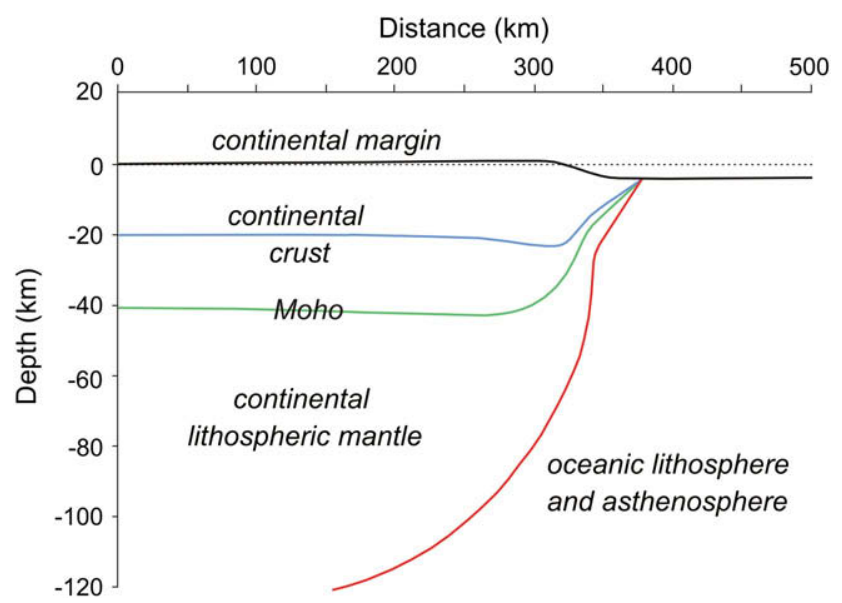

Fig. 11. Lithosphere cross-section for a volcanic rifted margin, after $12.5 \mathrm{Ma}$ of continental breakup thinning, followed by $12.5 \mathrm{Ma}$ of seafloor spreading, as modeled by Kusznir and Karner (2007). This model mimics the eastern margin of the Borborema Province, northeastern Brazil, where final breakup from Africa occurred around $105 \mathrm{Ma}$ (Jardim de Sá et al., 2005). Note thickening of continental crust and lithosphere towards the ocean-continent transition and a small amount of uplift $(<600 \mathrm{~m})$ of the adjacent hinterland. indicate that the Cabo granite ( $102 \mathrm{Ma}$; Souza et al., 2004) was exhumed up to $2 \mathrm{~km}$ before the deposition of the Albo-Cenomanian carbonates of the Estiva Formation (Almeida et al., 2005). In the Potiguar Basin, the Jandaíra Formation limestones also record evidence for a subaerial exposure ca. $89 \mathrm{Ma}$ (Gil, 1996), as well as for a significant erosive event on the top of the carbonate platform, suggesting that one or more pulses of uplift raised at least the southern portion of the Potiguar Basin during late Cretaceous to early Cenozoic (Cremonini et al., 1998; Soares et al., 2003). Indeed this event also correlates with the initiation of a wrenchingdominated stage that generated hiatuses and basin inversion in both Brazilian and African Equatorial Margins (Zalán et al., 1985; Attoh et al., 2004); according to Matos (2000), the final release of the South American and African plates along the Romanche Fracture Zone was completed by the mid Turonian (Fig. 4).

When a plate moves over anomalously warm mantle, surface uplifts of up to $500-1000 \mathrm{~m}$ can be generated and the resultant thermal doming can extend across a broad diffuse zone of more than $2000 \mathrm{~km}$ (White and McKenzie, 1989). Significant uplift also can be generated if mantle plume "tails" linger and deliver heat beneath the lithosphere over a period of 25-30 m.y., as modeled by Nyblade and Sleep (2003) to investigate the anomalous topography of the southern African Plateau. The rise of plume material undergoes decompressive melting, volcanism, and magmatic underplating (e.g., Coward, 1994). This way, an underplating mechanism seems to be a plausible interpretation to maintain the long-term Borborema topography and parallels the hypotheses of O'Connor and le Roex (1992) and Magnavita et al. (1994) in suggesting that plume systems may have played an important role in the development of broad zones of diffuse mid-plate volcanism in the central-south Atlantic.

Geophysical studies by Ussami et al. (1999) demonstrated the existence of a geoid anomaly across the whole Borborema Province. These authors suggested that the density variations responsible for the geoid anomaly are a consequence of deep-seated thermal effects in the mantle, probably related to post-rift magmatic events in northeastern Brazil, whose thermal effects have yet to be completely dissipated and thus might help engender topographic uplift and erosion during the Late Cenozoic.

In continental flood basalt provinces (e.g. Paraná, Karoo, Siberia and Deccan traps), where large magma volume exists, compared to the distribution of tholeiitic volcanics of the Borborema Province, similar mechanisms are also considered. Based on seismic and gravity data modeling, Shoko and Gwavava (1999) suggested crustal extension followed by magmatic underplating beneath the Cabora Bassa Basin (Zambezi rift) to explain crustal thickening and sustained uplift and erosion since the end of rifting in the Late Cretaceous/Early Cenozoic in southern Africa.

Where dated, the offshore volcanic activity of the NW-SE trending Paraíba, Pernambuco and Bahia seamounts is $85-78 \mathrm{Ma}$ (Cherkis et al., 1992), and are likely melts associated with the Martin Vaz-Trindade, Ascension and Saint Helena hot spot-plumes systems (Cherkis et al., 1992; O'Connor and le Roex, 1992; Ernesto, 2005). As the South American plate moved off the plume, thermal cooling and subsidence ensued. However, to maintain permanent topography of both the Borborema and Araripe areas, widespread magmatic underplating had to augment the crustal thickness. The lack of wide-angle seismologic data in northeastern Brazil makes it difficult to estimate the uplift magnitude resulting from the thickness of magmatic underplating. We can estimate the volume of underplated material necessary to maintain the regional, post-rift topography of northeastern Brazil, using the following relationship (e.g., Watts, 2001):

$u=\frac{\rho_{\mathrm{m}}-\rho_{\mathrm{v}}}{\rho_{\mathrm{m}}} h_{\mathrm{u}}$ 
where $u$ is the topographic relief, $h_{\mathrm{u}}$ is the thickness of the underplated layer, and $\rho_{\mathrm{m}}$ and $\rho_{\mathrm{v}}$ are the densities of the mantle and the magmatic underplate. Using this equation, a surface topography of 450-900 m implies an underplated layer thickness of 5-10 km (assuming a melt density of $3.0 \mathrm{~g} / \mathrm{cm}^{3}$ ) and for the area of the Borborema Plateau, requires a magma volume of $1.0-2.0 \times 10^{6} \mathrm{~km}^{3}$.

Previous interpretations linking Cenozoic volcanism as a causative mechanism for a major post-rift uplift of the Borborema Plateau (e.g., Almeida et al., 1988; Saadi, 1993; Jardim de Sá et al., 1999; Morais Neto et al., 2000; Morais Neto and Alkmin, 2001) are questionable, primarily because the thermal effects of the associated alkalic volcanism are minor. For the most part, the onshore Cenozoic magmatism consists of alkali basalts, which imply the rapid generation and emplacement of small volume melts and minor partial melting of upper mantle rocks (e.g., Oliveira, 1998). As such, the heat content of alkali volcanics is relatively low and thus it is unlikely that these Cenozoic volcanics could have been responsible for significant thermal doming. In addition, the implied timing is some $75-25 \mathrm{Ma}$ later than that required by the fission-track results (Fig. 3) and so this hypothesis should be treated with caution, until the establishment of more confident constraints about the age and geochemistry of those volcanics.

In the absence of an obvious and widespread thermal or magmatic mechanism (Fig. 4) to explain the Late Cenozoic cooling event (20-0 Ma), we take a different approach. As pointed out by Miller et al. (1998), during the Cenozoic, the world underwent a transition from the "greenhouse" world of relatively equitable temperatures spanning from low to high latitudes to the "icehouse" world of extreme equatorial-polar temperature gradients. Simultaneously, many continental margins also underwent major morphological changes as they transformed from predominantly carbonate ramps into prograding siliciclastic shelves (e.g., Pazzaglia and Gardner, 1994; Seranne, 1999; Gunnell and Fleitout, 2000; Pessoa Neto, 2003). We suggest that climate changes starting with the onset of Antarctic ice growth and the establishment of pole to equator climatic gradients, beginning in the Late Eocene/Early Oligocene, led to an increase of rainfall in regions that were previously arid. This is in accord with the initial deposition of the Early Miocene Barreiras Formation, the microfauna of which indicate a tropical climate at this time (Arai, 1997). We surmise that a significant increase in rainfall across northern and eastern Brazil was conducive to renewed erosion of pre-existing topography across the entire region (including the Borborema Province) and may be recorded in the fission-track data as the 20-0 Ma cooling event. Evidence for an overabundance of clastics in the Potiguar
Basin is supported by the presence of a large siliciclastic wedge prograding over the carbonate platform during the Cenozoic (Figs. 3 and 12). Neotectonic activity (e.g., Bezerra et al., 2001, 2008; Jardim de Sá, 2001; Morais Neto and Alkmin, 2001; Barreto et al., 2002) likely played a role in locally reactivating topography during Pliocene to Holocene times.

\section{Conclusions}

The results of 14 AFTA (apatite fission-track analysis) samples collected in two regional transects across the Borborema Plateau, northeastern Brazil, show clear evidence of higher temperatures in the past. Two episodes of cooling have been identified in Proterozoic igneous/metamorphic samples: (1) the first cooling event beginning some time between 100 and $90 \mathrm{Ma}$, and (2) a second cooling event in the Neogene between 20 and 0 Ma. Other less dominant events are also revealed in the data, as a possible cooling event during the Late Cretaceous-Early Eocene transition (65$50 \mathrm{Ma}$ ), which is in agreement with the thermal solutions observed in AFTA samples from the onshore Potiguar Basin (Morais Neto et al., in press). The most important result of this study is that the main cooling events identified by the fission-track results are widespread and recorded some $200-400 \mathrm{~km}$ from the regions of Cretaceous continental rifting. These relationships are interpreted as a consequence of thermal advection and cooling engendered by topographic erosion, as results demand kilometer-scale denudation of the crystalline basement (in the order of 1000-3000 m, since the mid Cretaceous breakup), consistent with the estimates for the southeastern Brazilian margin for the same period (Gallagher et al., 1994; Brown et al., 2000).

The most difficult aspect of interpreting fission-track analysis is to identify the mechanism(s) responsible for the topography that was subsequently eroded during these events. The 100-90 Ma cooling event postdates the breakup of Brazil and Africa (considering rift onset at $144 \mathrm{Ma}$ and breakup at $\sim 105 \mathrm{Ma}$ ). Similarly, the second cooling event (20-0 Ma) occurred at a time characterized by relative tectonic quiescence and a viable geodynamic mechanism for regional topographic generation at this time is problematic.

The presence of marine Albian limestones (Santana Formation) in the Araripe Basin that are now at elevations of $700-800 \mathrm{~m}$ is clear evidence for an epeirogenic uplift of the Borborema Province region sometime after their deposition. The existence of the Rio Ceará-Mirim tholeiite dike swarm emplaced between 145 and $125 \mathrm{Ma}$ in the southern onshore Potiguar Basin attests to the existence of anomalous mantle temperatures, which potentially

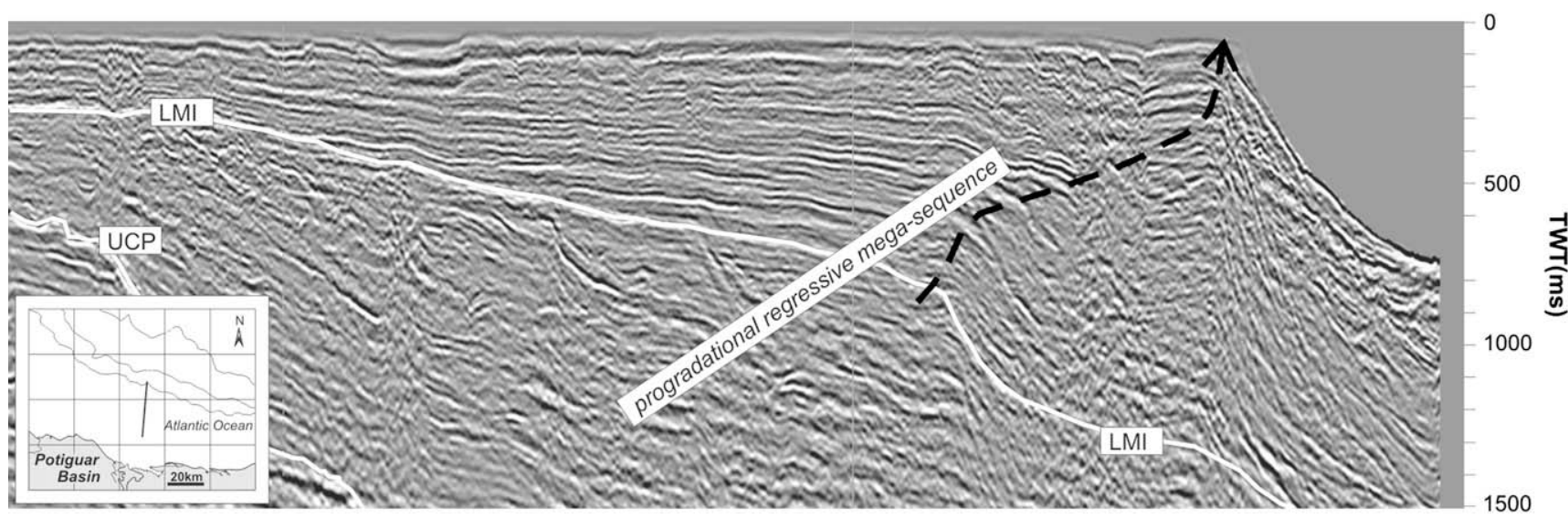

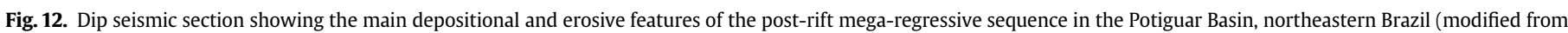

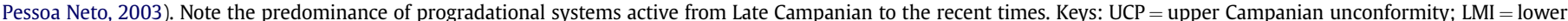
Miocene unconformity. 
allowed magmatic underplating of the crust generating permanent uplift over a broad geographic area. The candidates for these anomalous mantle temperatures are the Saint Helena and Ascension plumes. However: (1) the Aptian-Albian impingement of the plumes across the northeastern Brazilian interior and the 145$125 \mathrm{Ma}$ age of the Rio Ceará-Mirim tholeiite dike swarm are uncomfortably early relative to the $100-90 \mathrm{Ma}$ cooling event registered in the fission-track data; (2) the required $5-10 \mathrm{~km}$ of underplating necessary to support the 500-1000 m topography of the Borborema Plateau has not been confirmed by seismic refraction, although recent modeling of the free-air gravity "edge-effect" has shown that such a hypothesis is feasible (Oliveira and Medeiros, 2007) and (3) the regional distribution and large volume of magmatic material required is more diagnostic of major plumes such as Tristão da Cunha and Deccan (Wilson, 1992) rather than the "weak" Saint Helena and Ascension plumes.

Our preferred mechanism to generate the regional relief of northeastern Brazil relates to the consequences of depth-dependent lithospheric thinning during the Neocomian-Albian development of the Brazilian margins around northeastern Brazil. During depth-dependent thinning of volcanic type margins, an outward flow of crustal and lithospheric mantle material towards the hinterland is produced, thickening the adjacent continental lithosphere at distances significantly beyond the region of localized rifting and lithospheric thinning (400-600 km). During the subsequent thermal re-equilibration of the continental hinterland lithosphere geotherm, an uplift of 400-600 m over a timescale of 60-100 m.y. is produced (Kusznir and Karner, 2007).

Previous interpretations have linked the second cooling event (20-0 Ma) with thermal events related to the Cenozoic magmatic activity of northeastern Brazil. However, this time is somewhat younger than most of the volcanic activity, which is concentrated in the Oligocene-Miocene transition. This magmatism is also spatially restricted and is characterized by alkalic volcanism; such volcanism is known for its low thermal impact during and after emplacement. Instead, we suggest that climate changes associated with the production of the Antarctic ice sheet in the earliest Oligocene modified the climate in regions that were previously arid to climates conducive to the production of clastics. We surmise that a significant increase in rainfall across northern and eastern Brazil was conducive to renewed and reinvigorated erosion of pre-existing topography (the remainder of the topography generated and supported by Aptian-Albian magmatic underplating) across the entire region, including the Borborema Province.

In conclusion, we have shown how apatite fission-track thermal history solutions can be used to constrain important aspects of the vertical movement of the crust through time and to infer the timing of topographic denudation. This quantitative information is essential in transforming theoretical models about crustal behavior into testable and proven mechanisms for the generation of topography that are applicable to other provinces in the world. In this case, where we attempted to learn more about the generation and subsequent modification of the anomalous positive topography of the Borborema Plateau, the timing constraints afforded by our fission-track results allowed us to discard rift flank topography as the causative mechanism for the formation of the Borborema Plateau. Instead, post-extension lithospheric processes, possibly augmented by magmatic crustal underplating related to plume activity appear to be the most likely mechanisms for the generation of the large wavelength topography of northeastern Brazil, followed by subsequent erosion recorded in the fission-track data as a cooling event commencing sometime between 100 and 90 Ma. Further, the 20-0 Ma event is interpreted in terms of a climate change in the Neogene rather than engendered by tectonics. Both these conclusions must stand the test of further investigation, but presently serve as viable models that may be applied to any passive margin system.

\section{Acknowledgments}

We thank Petrobras and Federal University of Ouro Preto (Brazil) for financial support and fieldwork logistics as part of a postgraduate program of the first author. Geotrack International (Australia) was responsible for the apatite fission-track analyses of all the Borborema samples. The analytical results, ages and length data plots can be supplied to interested groups by request to the authors. Petrobras geologists Ubiraci Soares, Otaviano Pessoa Neto and Edison Milani, as well as former colleague Renato Matos, are thanked for many helpful suggestions and discussions on the Brazilian Equatorial Margin evolution and stratigraphy. We are also grateful to Jeffrey Weissel, Ricardo Bedregal, Paul Green and Ian Davison for their helpful comments and improvements on earlier versions of the manuscript. F. F. Alkmim received support from CNPq (Brazilian Council for the Scientific and Technological Development), grant \#300833/99-7.

\section{References}

Almeida, C.B., Cruz, L.R., Jardim de Sá, E.F., Vasconcelos, P.M.P., Medeiros, W.E., 2005. Tectônica e relações estratigráficas na sub-bacia de Pernambuco, NE do Brasil; contribuição ao conhecimento do rifte Sul-Atlântico. Boletim de Geociências da Petrobras 13 (2), 167-190.

Almeida, F.F.M., Carneiro, C.D.R., Machado Jr., D.L., Dehira, L.K., 1988. Magmatismo pós-paleozóico no Nordeste Oriental do Brasil. Revista Brasileira de Geociências 18 (4), 451-462.

Antonioli, L., Arai, M., 2002. O registro da ecozona Subtilisphaera na Formação Codó (Cretáceo Infeior da Bacia do Parnaíba, Nordeste do Brasil): seu significado paleogeográfico. In: $6^{\circ}$ Simpósio sobre o Cretáceo do Brasil, Rio Claro, Boletim de Resumos Expandidos, pp. 25-30.

Arai, M., 1997. Dinoflagelados (Dinophyceae) miocênicos do Grupo Barreiras do nordeste do Estado do Pará (Brasil). Revista Universidade Guarulhos Geociências 2 (Número Especial), 98-106.

Arai, M., Uesugui, N., Rossetti, D.F., Góes, A.M., 1988. Considerações sobre a idade do Grupo Barreiras no nordeste do estado do Pará. In: $35^{\circ}$ Congresso Brasileiro de Geologia, Belém, Annals, vol. 2, pp. 738-752.

Araripe, P.T., Feijó, F.J., 1994. Bacia Potiguar. Boletim de Geociências da Petrobras 8 (1), 127-141.

Attoh, K., Brown, L., Guo, J., Heanlein, J., 2004. Seismic stratigraphic record of transpression and uplift on the Romanche transform margin, offshore Ghana. Tectonophysics 378 (1-2), 1-16.

Barreto, A.M.F., Bezerra, F.H.R., Suguio, K., Tatumi, S.H., Yee, M., Paiva, R.P. Munita, C.S., 2002. Late Pleistocene marine terrace deposits in northeastern Brazil: sea-level change and tectonic implications. Palaeogeography Palaeoclimatology Palaeoecology 179 (1-2), 57-69.

Bezerra, F.H.R., Brito Neves, B.B., Corrêa, A.C.B., Barreto, A.M.F., Suguio, K., 2008. Late Pleistocene tectonic-geomorphological development within a passive margin The Cariatá trough, northeastern Brazil. Geomorphology 97, 555-582.

Bezerra, F.H.R., Amaro, V.E., Vita-Finzi, C., Saadi, A., 2001. Pliocene-quaternary fault control of sedimentation and coastal plain morphology in NE Brazil. Journal of South American Earth Sciences 14 (1), 61-75.

Bigarella, J.J., 1975. The Barreiras group in northeastern Brazil. Anais da Academia Brasileira de Ciências 47 (Suplemento), 365-393.

Bond, G.C., Kominz, M.A., 1988. Evolution of thought on passive continental margins from the origin of geosynclinal theory (approximately 1860) to the present. Geological Society of America Bulletin 100 (12), 1909-1933.

Bray, R., Munday, S., Green, P.F., Lawrence, S.R., 2002. Deformation and uplift history of the Eastern Gulf of Guinea - implications for petroleum prospectivity. In: PESGB-HGS: First Annual International Symposium. Africa, the success will continue, London 17-18 September 2002, p. 12.

Brito Neves, B.B., Santos, E.J., Van Schmus, W.R., 2000. Tectonic history of the Borborema Province, Northeastern Brazil. In: Cordani, U.G., Milani, E.J., Thomaz Filho, A., Campos, D.A. (Eds.), Tectonic Evolution of South America. 31st International Geological Congress, Rio de Janeiro, pp. 151-182.

Brodie, J., White, N., 1995. The link between sedimentary basin inversion and igneous underplating. In: Buchanan, J.G., Buchanan, P.G. (Eds.), Basin Inversion. Special Publication 88. Geological Society, London, pp. 21-38.

Brown, R.W., Gallagher, K., Gleadow, A.J.W., Summerfield, M.S., 2000. Morphotectonic evolution of the South Atlantic margins of Africa and South America. In: Summerfield, M.S. (Ed.), Geomorphology and Global Tectonics. John Wiley \& Sons, Chichester, pp. 255-284.

Cherkis, N.Z., Fleming, H.S., Brozena, J.M., 1989. Bathymetry of the South Atlantic Ocean $-3^{\circ} \mathrm{S}$ to $40^{\circ} \mathrm{S}$. In: GSA (Ed.), Map Chart Service MCH-069. Geological Society of America, Boulder.

Cherkis, N.Z., Chaves, D.A., Costa, L.C., 1992. The Bathymetry and distribution of the Bahia Seamounts, Brazil Basin. Marine Geology 103 (1-3), 335-347.

Coward, M., 1994. Inversion tectonics. In: Hancock, P.L. (Ed.), Continental Deformation. Pergamon Press, Oxford, pp. 289-304. 
Cremonini, O.A., 1996. Evolução tectônica da área de Ubarana, porção submersa da Bacia Potiguar. Boletim de Geociências da Petrobras 9 (1/4), 81-98.

Cremonini, O.A., Karner, G.D., 1995. Soerguimento termal e erosão na Bacia Potiguar submersa, e seu relacionamento com a evolução da margem equatorial brasileira. In: XVI Simpósio de Geologia do Nordeste, Recife, Boletim 14, pp. 181-184.

Cremonini, O.A., Goulart, J.P.M., Soares, U.M., 1998. Tectono-stratigraphic evolution of offshore Potiguar Basin, Brazil. In: AAPG International Conference and Exhibition, Rio de Janeiro, Extended Abstract Volume, pp. 44-45.

Dantas, E.L., Hackspacher, P.C., Schmus, W.R.V., Neves, B.B.B., 1998. Archean accretion in the São José do Campestre Massif, Borborema province, northeast Brazil. Revista Brasileira de Geociências 28 (2), 221-229.

Davis, M., Kusznir, N.J., 2004. Depth-dependent lithospheric stretching at rifted continental margins. In: Karner, G.D., Taylor, B., Driscoll, N.W., Kohlstedt, D.L (Eds.), Rheology and Deformation of the Lithosphere at Continental Margins. Columbia University Press, New York, pp. 92-136.

Destro, N., Szatmari, P., Ladeira, E.A., 1994. Post-Devonian transpressional reactivation of a Proterozoic Ductile Shear Zone in Ceará, NE Brazil. Journal of Structural Geology 16 (1), 35-45.

Duddy, I.R., Green, P.F., Laslett, G.M., 1988. Thermal annealing of fission tracks in apatite - 3. Variable temperature behaviour. Chemical Geology (Isotope Geoscience Section) 73, 25-38.

Ernesto, M., 2005. Paleomagnetism of the post-paleozoic alkaline magmatism in the Brazilian Platform: questioning the mantle plume model. In: CominChiaramonti, P., Gomes, C.B. (Eds.), Mesozoic to Cenozoic Alkaline Magmatism in the Brazilian Platform. EDUSP/FAPESP, São Paulo, pp. 689-705.

Fairhead, J.D., Wilson, M., 2005. Plate tectonic processes in the South Atlantic Ocean: do we need deep mantle plumes? In: Foulger, G.R., Natland, J.H. Pressnall, D.C., Anderson, D.L. (Eds.), Plates, Plumes and Paradigms. Special Paper 388. Geological Society of America, pp. 537-553.

Feijó, F.J., 1996. O início da livre circulação das águas do Oceano Atlântico. Boletim de Geociências da Petrobras 9 (1/4), 157-164

Fleischer, R.L., Price, P.B., Walker, R.M., 1975. Nuclear Tracks in Solids-Principles and Applications. University of California Press, Berkeley, 605 pp.

Gallagher, K., Hawkesworth, C.J., Mantovani, M.S.M., 1994. The denudation history of the onshore continental margin of the SE Brazil inferred from apatite fission track data. Journal of Geophysical Research 99 (B9), 18117-18145.

Gallagher, K., Brown, R., Johnson, C., 1998. Fission track analysis and its application to geolgical problems. Annual Review of Earth and Planetary Sciences 26, 519-572.

Gil, J.A., 1996. Estratigrafia e análise paleoambiental da plataforma carbonática Jandaíra; turoniano-campaniano da porção centro-oeste da Bacia Potiguar. Unpublished Master Thesis, UFRGS, Porto Alegre, $146 \mathrm{pp}$.

Gleadow, A.J.W., Duddy, I.R., Lovering, J.F., 1983. Fission track analysis: a new tool for the evaluation of thermal histories and hidrocarbon potential. The Australian Petroleum Exploration Association Journal 23, 93-102.

Gleadow, A.J.W., Duddy, I.R., Green, P.F., Lovering, J.F., 1986. Confined fission track lengths in apatite - a diagnostic tool for thermal history analysis. Contribution to Mineralogy and Petrology 94, 405-415

Gleadow, A.J.W., Kohn, B.P., Brown, R.W., O’Sullivan, P.B., Raza, A., 2002. Fission track thermotectonic imaging of the Australian continent. Tectonophysics 349 (1-4) $5-21$.

Green, P.F., Duddy, I.R., Gleadow, A.J.W., Tingate, P.T., Laslett, G.M., 1986. Thermal annealing of fission tracks in apatite 1-A qualitative description. Chemical Geology 59, 237-253.

Green, P.F., Duddy, I.R., Gleadow, A.J.W., Lovering, J.F., 1989a. Apatite fission track analysis as a palaeotemperature indicator for hydrocarbon exploration. In: Naeser, N.D., McCulloh, T.W. (Eds.), Thermal history of sedimentary basins methods and case histories. Springer-Verlag, New York, pp. 181-195.

Green, P.F., Duddy, I.R., Laslett, G.M., Hegarty, K.A., Gleadow, A.J.W., Lovering, J.F. 1989b. Thermal annealing of fission tracks in apatite 4-quantitative modeling techniques and extension to geological timescales. Chemical Geology 79 (2) 155-182.

Green, P.F., Hegarty, K.A., Duddy, I.R., 1996. Compositional influences on fission track annealing in apatite and improvement in routine application of AFTA ${ }^{(B)}$. In: AAPG Meeting, San Diego, Annual Meeting Abstracts, vol. 5. AAPG/SEPM A.56.

Guiraud, R., Bosworth, W., 1997. Senonian basin inversion and rejuvenation of rifting in Africa and Arabia: synthesis and implications to plate-scale tectonics. Tectonophysics 282 (1-4), 39-82.

Gunnell, Y., Fleitout, L., 2000. Morphotectonic evolution of the Western Ghats, India. In: Summerfield, M.A. (Ed.), Geomorphology and Global Tectonics. John Wiley \& Sons Ltd., Chichester, pp. 320-368.

Hackspacher, P.C., Ribeiro, L.F.B., Ribeiro, M.C.S., Fetter, A.H., Hadler Neto, J.C.H., Tello, C.E.S., Dantas, E.L., 2004. Consolidation and break-up of the South American platform in southeastern Brazil: tectonothermal and denudation histories. Gondwana Research 7 (1), 91-101.

Harman, R., Gallagher, K., Brown, R., Razza, A., Bizzi, L., 1998. Accelerated denudation and tectonic/geomorphic reactivation of the cratons of northeastern Brazi during the Late Cretaceous. Journal of Geophysical Research - Solid Earth 103 (11), 27091-27105

Hegarty, K.A., Duddy, I.R., Green, P.F., 1996. The thermal history in and around the Paraná Basin using apatite fission track analysis - implications for hydrocarbon occurrences and basin formation. In: Comin-Chiaramonti, P., Gomes, C.B. (Eds.) Alkaline Magmatism in Central-Eastern ParaguayRelationships with coeval magmatism in Brazil. USP, São Paulo, pp. 67-84.
Hegarty, K.A., Morais Neto, J.M., Karner, G.D., 2002. The enigma of the Araripe Plateau - new constraints on its uplift and tectonic history using AFTA. In: $41^{\circ}$ Congresso Brasileiro de Geologia, João Pessoa, Abstracts Volume, p. 495.

Hegarty, K.A., Morais Neto, J.M., Karner, G.D., 2004. Mapping anomalous topography through time and understanding its origins - a study of the Borborema Province, NE Brazil. In: 32nd International Geological Congress, Florence, Abstracts CD, p. G05.08

Issler, D.R., Willett, S.D., Beaumont, C., Donelick, I.A., Grist, A.M., 1999. Paleotemperature history of two transects across the Western Canada Sedimentary Basin: constraints from apatite fission track analysis. Bulletin of Canadian Petroleum Geology 47 (4), 475-486.

Jardim de Sá, E.F., 1994. A Faixa Seridó (Província Borborema, Nordeste do Brasil) e seu significado geodinâmico na Cadeia Brasiliana/Pan-Africana. Unpublished PhD Thesis, Universidade de Brasília, Brasília, 803 pp.

Jardim de Sá, E.F., Matos, R.M.D., Morais Neto, J.M., Pessoa Neto, O.C., Saadi, A., 1999. Epirogenia cenozóica na Província Borborema: síntese e discussão sobre os modelos de deformação associados. In: VII Simpósio Nacional de Estudos Tectônicos - I International Symposium on Tectonics, Lençóis, Annals, pp. S4:58-61.

Jardim de Sá, E.F., 2001. Tectônica cenozóica na margem equatorial da Província Borborema, Nordeste do Brasil (A contribuição da Geologia Estrutural no continente). In: VIII Simpósio Nacional de Estudos Tectônicos - II International Symposium on Tectonics, Recife, Annals, pp. 25-28.

Jardim de Sá, E.F., Vasconcelos, P.M., Kohn, B.P., Matos, R.M.D., Nascimento, M.A.L., Souza, Z.S., 2004. Datações Ar/Ar do magmatismo Ipojuca e a idade do rifteamento na sub-bacia de Pernambuco, Nordeste do Brasil. In: $42^{\circ}$ Congresso Brasileiro de Geologia, Araxá, Abstracts CD, p. S32.399.

Jardim de Sá, E.F., Souza, Z.S., Vasconcelos, P.M., Saadi, A., Galindo, A.C., et al., 2005. Marcos Temporais para a Evolução Cenozóica do Planalto da Borborema. In: X Simpósio Nacional de Estudos Tectônicos - IV International Symposium on Tectonics. SBG, Curitiba, Abstracts CD, pp. 160-162.

Karner, G.D., Ussami, N., Alkimim, F.F., 1994. Tectonic significance of the topography of southeastern Brazil: speculations and implications. Revista da Escola de Minas 47 (1), 18-19.

Koutsoukos, E.A.M., 1992. Late Aptian to Maastrichtian Foraminiferal Biogeography and Paleoceanography of the Sergipe Basin, Brazil. Palaeogeography Palaeoclimatology Palaeoecology 92 (3-4), 295-324.

Kusznir, N.J., Karner, G.D., 2007. Continental lithospheric thinning and breakup in response to upwelling divergent mantle flow: application to the Woodlark, Newfoundland and Iberia margins. In: Karner, G.D., Manatschal, G., Pinheiro, L. (Eds.), Imaging, mapping and modeling continental lithosphere extension and breakup. Special Publication 282. Geological Society, London, pp. 389-419.

Lana, M.C., 1990. Bacia de Sergipe-Alagoas: uma hipótese de evolução tectonosedimentar. In: Raja Gabaglia, G.P., Milani, E.J. (Eds.), Origem e Evolução de bacias sedimentares. PETROBRAS, Rio de Janeiro, pp. 311-332.

Laslett, G.M., Green, P.F., Duddy, I.R., Gleadow, A.J.W., 1987. Thermal annealing of fission tracks in apatite -2 . A quantitative analysis. Chemical Geology (Isotope Geoscience Section) 65, 1-13.

Lim, H.S., Lee, Y.I., Mim, K.D., 2003. Thermal history of the Cretaceous Sindong Grup, Gyeongsang Basin, Korea based on fission track analysis. Basin Research 15, 139-152.

Lima, M.G., Vasconcelos, P.M., Farley, K.A., Jardim de Sá, E.F., 2007. Datação do intemperismo impõe limites na idade da Formação Barreiras, Bacia Potiguar, nordeste do Brasil. In: XI Conferência da Associação Brasileira de Estudos do Quaternário, Belém, Abstracts CD.

Lima Filho, M.L., Szatmari, P., 2002. Ar-Ar geochronology of volcanic rocks of the Cabo Magmatic Province (CMP) - Pernambuco Basin. In: II Simpósio sobre vulcanismo e ambientes associados, Belém, Abstracts Volume, p. 59.

Lima Neto, F.F., 1998a. O exemplo da interferência mecânica de uma interface fraca: o campo atual de tensões na Bacia Potiguar. Unpublished Master Thesis, Universidade Federal de Ouro Preto, Ouro Preto, 320 pp.

Lima Neto, F.F., 1998b. Evolução pós-paleozóica do nordeste brasileiro: "hot spots" em manto frio. In: $40^{\circ}$ Congresso Brasileiro de Geologia, Belo Horizonte, Abstract Volume, p. 103

Long, L.E., Sial, A.N., Nekvasil, H., Borba, G.S., 1986. Origin of Granite at Cabo De Santo Agostinho, Northeast Brazil. Contributions to Mineralogy and Petrology 92 (3), 341-350.

Mabesoone, J.M., Campos e Silva, A., Beurlen, K., 1972. Estratigrafia e origem do Grupo Barreiras em Pernambuco, Paraíba e Rio Grande do Norte. Revista Brasileira de Geociências 2 (3), 173-188.

Magnavita, L.P., Davison, I., Kusznir, N.J., 1994. Rifting, erosion, and uplift history of the Reconcavo-Tucano-Jatoba rift, northeast Brazil. Tectonics 13 (2), 367-388.

Matos, R.M.D., 1992. The northeast Brazilian rift system. Tectonics 11 (4), 766-791.

Matos, R.M.D., 1999. History of the northeast Brazilian rift system: kinematic implications for the break-up between Brazil and West Africa. In: Cameron, N.R., Bate, R.H., Clure, V.S. (Eds.), The Oil and Gas Habitats of the South Atlantic. Special Publication 153. Geological Society, London, pp. 55-73.

Matos, R.M.D., 2000. Tectonic evolution of the Equatorial South Atlantic. In: Mohriak, W., Talwani, M. (Eds.), Atlantic rifts and continental margins. Geophysical Monograph 115. Geological Society/AGU, pp. 331-354.

Matos, R.M.D., 2001. Mantle-plume-generated triple junction between NE Brazil and West Africa? In: 7th International Congress of the Brazilian Geophysical Society. Salvador, Abstracts Volume, pp. 45-48.

Menezes, M.R.F., Morais Neto, J.M., Szatmari, P. and York, D., 2003. Relações cronológicas entre o vulcanismo Macau e a Formação Serra do Martins, com base 
na datação Ar/Ar do plug basáltico "Serrote Preto" (RN, Nordeste do Brasil). In: IX Simpósio Nacional de Estudos Tectônicos - IIII International Symposium on Tectonics, Búzios, Annals, pp. 246-249.

Miller, K.G., Mountain, G.S., Browning, J.V., Kominz, M., Sugarman, P.J., ChristieBlick, N., Katz, M.E., Wright, J.D., 1998. Cenozoic global sea level, sequences, and the New Jersey transect: results from coastal plain and continental slope drilling. Reviews of Geophysics 36 (4), 569-601.

Mizusaki, A.M.P., 1989. A Formação Macau na porção submersa da Bacia Potiguar. Boletim de Geociências da Petrobras 3 (3), 191-200.

Mizusaki, A.M.P., Thomaz-Filho, A., Milani, E.J., de Cesero, P., 2002. Mesozoic and Cenozoic igneous activity and its tectonic control in northeastern Brazil. Journal of South American Earth Sciences 15 (2), 183-198.

Mohriak, W.U., Bassetto, M., Vieira, I.S., 1998. Crustal architecture and tectonic evolution of the Sergipe-Alagoas and Jacuipe basins, offshore northeastern Brazil. Tectonophysics 288 (1-4), 199-220.

Mohriak, W.U., Rosendahl, B.R., Turner, J.P., Valente, S.C., 2002. Crustal architecture of South Atlantic volcanic margins. In: Menzies, M.A., Klemperer, S.L., Ebinger, C.J., Baker, J. (Eds.), Volcanic rifted margins. Special Paper 363. The Geological Society of America, pp. 159-202.

Morais Neto, J.M., 1999. As coberturas sedimentares terciárias do interior da Paraíba e Rio Grande do Norte e a gênese da Antéclise da Borborema. Unpublished Master Thesis, Universidade Federal de Ouro Preto, Brazil, Ouro Preto, 170 p.

Morais Neto, J.M., Alkmin, F.F., 2001. A deformação das coberturas terciárias do Planalto da Borborema (PB-RN) e seu significado tectônico. Revista Brasileira de Geociências 31 (1), 95-106.

Morais Neto, J.M., Hegarty, K., Karner, G.D., 2006. Abordagem preliminar sobre paleotemperatura e evolução do relevo da bacia do Araripe, nordeste do Brasil, a partir da análise de traços de fissão em apatita. Boletim de Geociências da Petrobras 14 (1), 113-118.

Morais Neto, J.M., Hegarty, K.A., Alkmin, F.F., Matos, R.M.D., Karner, G.D., 2000. Uplift and erosion in the Borborema Province, Northeast Brazil: insights from apatite fission track analysis. In: 31st International Geological Congress. Rio de Janeiro, Abstract CD, p. GS 18.1 .

Morais Neto, J. M., Green, P.F., Karner, G.D., Alkmim, F.F., Age of the Serra do Martins Formation, Borborema Province, northeastern Brazil: constraints from apatite and zircon fission track analysis. Boletim de Geociências da Petrobras, in press.

Nóbrega, M.A., Sá, J.M., Bezerra, F.H.R., Hadler, J.C., Iunes, P.J., Guedes, S. Saenz, C.A.T., Hackspacher, P.C., Lima Filho, R., 2005. The use of apatite fission track thermochronology to constrain fault movements and sedimentary basin evolution in northeastern Brazil. Radiation Measurements 39 (6), 627-633.

Nyblade, A.A., Sleep, N.H., 2003. Long lasting epeirogenic uplift from mantle plumes and the origin of the Southern African Plateau. Geochemistry Geophysics Geosystems 4 (12), 1105, doi:10.1029/2003GC000573.

O'Connor, J.M., Duncan, R.A., 1990. Evolution of the Walvis Ridge-Rio Grande Rise hot spot system, implications for African and South American plate motions over plumes. Journal of Geophysical Research 95, 17475-17502.

O'Connor, J.M., le Roex, A.P., 1992. South Atlantic hot spot-plume systems: 1 Distribution of volcanism in time and space. Earth and Planetary Science Letters $113,343-364$.

Oliveira, D.C., 1993. O papel do enxame de diques Rio Ceará Mirim na evolução tectônica do nordeste oriental (Brasil): implicações na formação do Rifte Potiguar. Unpublished Mater Thesis, Universidade Federal de Ouro Preto, Ouro Preto, 172 pp.

Oliveira, D.C., 1998. Evolução magmática da Bacia Potiguar. In: $40^{\circ}$ Congresso Brasileiro de Geologia, Belo Horizonte, Abstracts Volume p. 102

Oliveira, R.G., Medeiros, W.E., 2007. O efeito gravimétrico de borda da margem continental da Província Borborema NE do Brasil: segmentações, arcabouço crustal e implicações para a evolução termo-mecânica das bacias sedimentares. In: 10th International Congress of the Brazilian Geophysical Society. Rio de Janeiro, Abstracts CD, Thermo-Mechanical Properties of Lithosphere Session, 6p.

Osadetz, K.G., Kohn, B.P., Feinstein, S., O'Sullivan, P.B., 2002. Thermal history of Canadian Williston basin from apatite fission-track thermochronology - implications for petroleum systems and geodynamic history. Tectonophysics 349 (1-4), 221-249.

Pazzaglia, F.J., Gardner, T.W., 1994. Late Cenozoic Flexural Deformation of the Middle United-States Atlantic Passive Margin. Journal of Geophysical Research - Solid Earth 99 (B6), 12143-12157.
Pereira, M.J., 1994. Sequências deposicionais de $2^{\mathrm{a}}$ e $3^{\mathrm{a}}$ ordens (50 a 2 Ma) e tectonoestratigrafia no Cretáceo de cinco bacias marginais do Brasil, comparações com outras áreas do globo. Unpublished Doctorate Thesis, Universidade Federal do Rio Grande do Sul, Porto Alegre, 430 pp.

Pessoa Neto, O.C., 2003. Estratigrafia de seqüências da plataforma mista neogênica na Bacia Potiguar, margem equatorial brasileira. Revista Brasileira de Geociências 33 (3), 263-278.

Peulvast, J.-P., Sales, V.C., Betard, F., Gunnell, Y., 2008. Low post-Cenomanian denudation depths across the Brazilian Northeast: implications for long-term andscape evolution at a transform continental margin. Global and Planetary Change 62 (1-2), 39-60.

Ponte, F.C., Ponte Filho, F.C., 1990. Caracterização estratigráfica da Formação Abaiara, Cretácio Inferior da Bacia do Araripe. In: $2^{\circ}$ Simpósio sobre as Bacias Cretácicas Brasileiras, Rio Claro, Abstracts Volume, pp. 61-64.

Saadi, A., 1993. Neotectônica da plataforma brasileira: esboço e interpretação preliminares. Geonomos 1 (1) 1-15.

Seranne, M., 1999. Early Oligocene stratigraphic turnover on the west Africa continental margin: a signature of the Tertiary greenhouse-to-icehouse transition? Terra Nova 11 (4), 135-140.

Shimabukuro, S., Arai, M., 1999. A transgressão marinha miocênica no Brasil: considerações baseadas no estudo do Grupo Barreiras e da Fm Pirabas. Anais da Academia Brasileira de Ciências 71 (1), 144.

Shoko, D.S.M., Gwavava, O., 1999. Is magmatic underplating the cause of post-rift uplift and erosion within the Cabora Bassa Basin, Zambezi Rift, Zimbabwe? Journal of African Earth Sciences 28 (2), 465-485.

Sial, A.N., 1976. The post-paleozoic volcanism of Northeast Brazil and its tectonic significance. Anais da Academia Brasileira de Ciências 48 (Suplemento), 299-311.

Soares, U.M., Rossetti, E.L., Cassab, R.C.T., 2003. Bacias sedimentares brasileiras Bacia Potiguar. Phoenix 56, 1-6.

Souza, Z.S., Vasconcelos, P.M., Nascimento, M.A.L., Silveira, F.V., Paiva, H.S., Dias, L.G.S., et al., 2004. Geocronologia e geoquímica do magmatismo cretácico a terciário no nordeste do Brazil. In: $42^{\circ}$ Congresso Brasileiro de Geologia Araxá, Abstracts CD, p. S32-T607.

Stockli, D.F., Dumitru, T.A., McWilliams, M.O., Farley, K.A., 2003. Cenozoic tectonic evolution of the White Mountains, California and Nevada. Geological Society of America Bulletin 115 (7), 788-816.

Thomaz Filho, A., Mizusaki, A.M.P., Milani, E.J., Césero, P., 2000. Rifting and magmatism associated with the South America and Africa break-up. Revista Brasileira de Geociências 30 (1), 17-19.

Ussami, N., Molina, E.C. and Medeiros, W.E., 1999. Novos vínculos sobre a evolução térmica da margem continental leste do Brasil. In: VII Simpósio Nacional de Estudos Tectônicos - I International Symposium on Tectonics, Lençóis, Annals, pp. S3:20-23.

Van Schmus, W.R., Brito Neves, B.B., Hackspacher, P.C., Fetter, A.H., Kozuch, M. Dantas, E.L., 1998. The Borborema Province: a collage of polycyclic crustal domains in NE Brazil. In: 14th International Conference on Basement Tectonics. UFOP/IBTA, Ouro Preto, Abstracts Volume, pp. 81-83.

Vauchez, A., Neves, S.P., Caby, R., Corsini, M., Silva, M.E., Arthaud, M., Amaro, V.E., 1995. The Borborema Shear Zone System, NE Brazil. Journal of South American Earth Sciences 8 (3-4), 247-266.

Watts, A.B., 2001. Isostasy and Flexure of the Lithosphere. Cambridge University Press, Cambridge, 458 pp.

White, R., McKenzie, D., 1989. Magmatism at rift zones - the generation of volcanic continental margins and flood basalts. Journal of Geophysical Research - Solid Earth and Planets 94 (B6), 7685-7729.

Wilson, M., 1992. Magmatism and continental rifting during the opening of the South Atlantic Ocean: a consequence of Lower Cretaceous super-plume activity? In: Storey, B.C., Alabaster, T., Pankhurst, R.J. (Eds.), Magmatism and the Causes of Continental Break-up. Special Publication 68 Geological Society, London, pp. 241-255.

Zalán, P.V., Nelson, E.P., Warme, J.E., Davis, T.L., 1985. The Piauí basin: rifting and wrenching in a equatorial Atlantic transform basin. In: Biddle, K., ChristieBlick, N. (Eds.), Strike-slip Deformation, Basin Formation and Sedimentation. Special Publication 17. SEPM, Tulsa, pp. 177-192. 